\title{
A palaeoenvironmental reconstruction of the Middle Jurassic of Sardinia (Italy) based on integrated palaeobotanical, palynological and lithofacies data assessment
}

\author{
Luca Giacomo Costamagna $^{1}$ - Evelyn Kustatscher ${ }^{2,3}$ (D) Giovanni Giuseppe Scanu ${ }^{1}$. \\ Myriam Del Rio ${ }^{1}$ Paola Pittau ${ }^{1}$. Johanna H. A. van Konijnenburg-van Cittert ${ }^{4,5}$
}

Received: 15 May 2017 / Accepted: 19 September 2017 /Published online: 17 November 2017

(C) The Author(s) 2017. This article is an open access publication

\begin{abstract}
During the Jurassic, Sardinia was close to continental Europe. Emerged lands started from a single island forming in time a progressively sinking archipelago. This complex palaeogeographic situation gave origin to a
\end{abstract}

This article is a contribution to the special issue "Jurassic biodiversity and terrestrial environments".

Evelyn Kustatscher

Evelyn.Kustatscher@naturmuseum.it

Luca Giacomo Costamagna

lucakost@unica.it

Giovanni Giuseppe Scanu

gioscanu@gmail.com

Myriam Del Rio

myriamdelrio6@gmail.com

Paola Pittau

paolapittau@gmail.com

Johanna H. A. van Konijnenburg-van Cittert jtvk@kgk.nl

1 Dipartimento di Scienze Chimiche e Geologiche, Università di Cagliari, via Trentino 51, 09127 Cagliari, Italy

2 Museum of Nature South Tyrol, Bindergasse/via Bottai 1, 39100 Bozen/Bolzano, Italy

3 Department für Geo- und Umweltwissenschaften, Paläontologie und Geobiologie, Ludwig-Maximilians-Universität und Bayerische Staatssammlung für Paläontologie und Geologie, Richard-Wagner-Straße 10, 80333 Munich, Germany

4 Laboratory of Palaeobotany and Palynology, Heidelberglaan 2, 3584 CS Utrecht, The Netherlands

5 Naturalis Biodiversity Center, PO Box 9517, 2300 RA Leiden, The Netherlands diverse landscape with a variety of habitats. Collectionand literature-based palaeobotanical, palynological and lithofacies studies were carried out on the Genna Selole Formation for palaeoenvironmental interpretations. They evidence a generally warm and humid climate, affected occasionally by drier periods. Several distinct ecosystems can be discerned in this climate, including alluvial fans with braided streams (Laconi-Gadoni lithofacies), paralic swamps and coasts (Nurri-Escalaplano lithofacies), and lagoons and shallow marine environments (UssassaiPerdasdefogu lithofacies). The non-marine environments were covered by extensive lowland and a reduced coastal and tidally influenced environment. Both the river and the upland/hinterland environments are of limited impact for the reconstruction. The difference between the composition of the palynological and palaeobotanical associations evidence the discrepancies obtained using only one of those proxies. The macroremains reflect the local palaeoenvironments better, although subjected to a transport bias (e.g. missing upland elements and delicate organs), whereas the palynomorphs permit to reconstruct the regional palaeoclimate. Considering that the flora of Sardinia is the southernmost of all Middle Jurassic European floras, this multidisciplinary study increases our understanding of the terrestrial environments during that period of time.

Keywords Jurassic · Bajocian-Bathonian · Palaeoecology · SEG $\cdot$ PEG $\cdot$ Sedimentology $\cdot$ Non-marine environments

\section{Introduction}

In the last decades, the focus of many Mesozoic palaeobotanical studies diverged from taxonomic studies of a single fossil assemblage, to palaeoenvironmental, palaeoclimatic and/or 
palaeo(bio)geographic reconstructions (e.g. Kustatscher et al. 2010, 2012, 2014; Kostina et al. 2015; Barbacka et al. 2014, 2016 and references therein). Palynomorphs are one of the most used proxies, due to the abundance of remains and the close relationship between the composition of the vegetation and climatic/environmental changes. The palynological record reflects, however, a mixed signal of global, regional and local origin. Thus, in the last years, they were often used combined with other proxies such as geochemistry if the question was of global and supra-regional nature (e.g. Van de Schootbrugge 2010; McElwain 1998) or with plant macroremains if the local/regional signal was more interesting (e.g. Parrish et al. 2004; Kustatscher et al. 2010, 2012, 2014, 2016, 2017; Götz et al. 2011; Barbacka et al. 2014; Barth et al. 2014; Franz et al. 2015; Li et al. 2015). Macromorphology and cuticles were used when the adaptation of plants to their environment was the focus (e.g. Barbacka et al. 2006; Pott et al. 2007, 2008; Pott and McLoughlin 2009; Steinthorsdottir et al. 2011). Additionally, authors proposed quantitative analyses on plant macroremains (e.g. Spicer and Hill 1979; Knobloch and Mai 1986; Herman and Spicer 1997; Rees et al. 2000; McElwain et al. 2007; Barbacka 2011; Barbacka et al. 2014; Kostina and Herman 2013) and on palynomorphs (e.g. Visscher and Van der Zwan 1981; El Beialy et al. 2002; Abbink 1998; Abbink et al. 2004; Jasper et al. 2010) for palaeoenvironmental interpretations. Moreover, qualitative and quantitative analyses on macroremains were also used to distinguish phytoprovinces (Vakhrameev 1991) and biomes (Rees et al. 2000).

The aim of this study is to use combined palaeobotanical, palynological and lithofacies studies for a palaeoenvironmental and palaeoclimatic reconstruction of the Middle Jurassic of Sardinia analysing the content and the features of the continental to transitional Genna Selole Formation (Dieni et al. 1983). The position of Sardinia during the Middle Jurassic was exceptional. As part of the Corsica-Sardinia block, it was located on the north-western edge of the Tethys and part of the margin of the European plate (Carmignani et al. 2001; Dercourt et al. 2000; Costamagna et al. 2007; Jadoul et al. 2010). This palaeogeographic position during the Jurassic makes Sardinia also of particular interest for palaeobiogeographic studies, although so far, there is no information available on the composition of the vertebrate and invertebrate fauna colonising the emerged islands except for some freshwater branchiopod crustaceans found in the fine-grained lithology (Krasser 1920; Kustatscher et al. 2016), whereas the rich macroflora and palynoflora of the Genna Selole Formation have been studied in the last 150 years (Del Rio 1976, 1990; Schneider 1978; Ashraf et al. 1984; Salard-Cheboldaeff in Dieni et al. 1983; Scanu et al. 2015, 2016; Kustatscher et al. 2016 and references therein).

\section{Materials and methods}

Outcrops of the Middle Jurassic of Sardinia yielding plant fossils and palynomorphs (Fig. 1) are restricted to the Genna Selole Formation (Scanu et al. 2012; Costamagna 2015, 2016). The more than 700 rock slabs with Jurassic plant macrofossils discussed in this paper come from three fossil collections. Plant fossils stored in the Lovisato Collection in the Geological and Paleontological Museum of the Cagliari University (collection A; 470 specimens) were mostly collected by Alberto Lamarmora, Domenico Lovisato and Alexander Tornquist (prefix "MGPDL", Scanu et al. 2012, 2015). Bombings in the Second World War severely damaged the remains and almost all information about the sampling localities has been lost. The second part of the Lovisato Collection (collection B; 134 specimens) is stored today in the Faculty of Sciences of the Charles University in Prague (Czech Republic, prefix Lov. B; Krasser 1920; Edwards 1929; Kustatscher et al. 2016). The labels are preserved indicating Laconi and other nearby localities. The plant macroremains of the two Lovisato collections are preserved on rock slabs of two different lithologies. Lithofacies 1 is composed of a mixed medium-fine to fine sandstone with occasional carbonate cementation, light grey to red in colour, sometimes with iron oxides or limonite. The plant remains are preserved as impressions with a mineralized crust. Lithofacies 2 includes fine, grey to dark grey siltstones. Most of the plant remains, including abundant indeterminable plant fragments, are preserved on this rock type. A small, artificially selected collection (Domenico Miccolis Collection, 21 specimens) is stored at the Natural History Museum of Venice (prefix "MSNVE"; Scanu et al. 2016). In this collection, all plant remains were preserved on rock slabs composed of grey to dark grey siltstones of lithofacies 2 . Quantitative analyses of the macrofossils are based on the counting of each identifiable plant fragment on both sides of the rock slabs in all three collections; parts and counterparts were counted as one. Plant fossils were divided into groups according to the different lithofacies in order to identify differences in composition and co-occurrences between the facies types. The plant fossils, then, were related to their presumed environments (plant ecogroup (PEG)), based on literature data, morphological and cuticular characters and sedimentology.

Palynological data from literature take into account 20 samples from 11 different Middle Jurassic localities, located respectively in the northern (three localities) and centraleastern (eight localities) part of Sardinia (Fig. 1). The data from the Tavolara (northeastern Sardinia) section were not used because D'Amato Avanzi (1974) discussed laevigate trilete spores only and slides are not available anymore. In the northern part of Sardinia (Nurra region), samples have been collected from blackish shales located in carbonate sections located at Fiume Santo, Mt. Rosé and Mt. Vaccargiu. For 


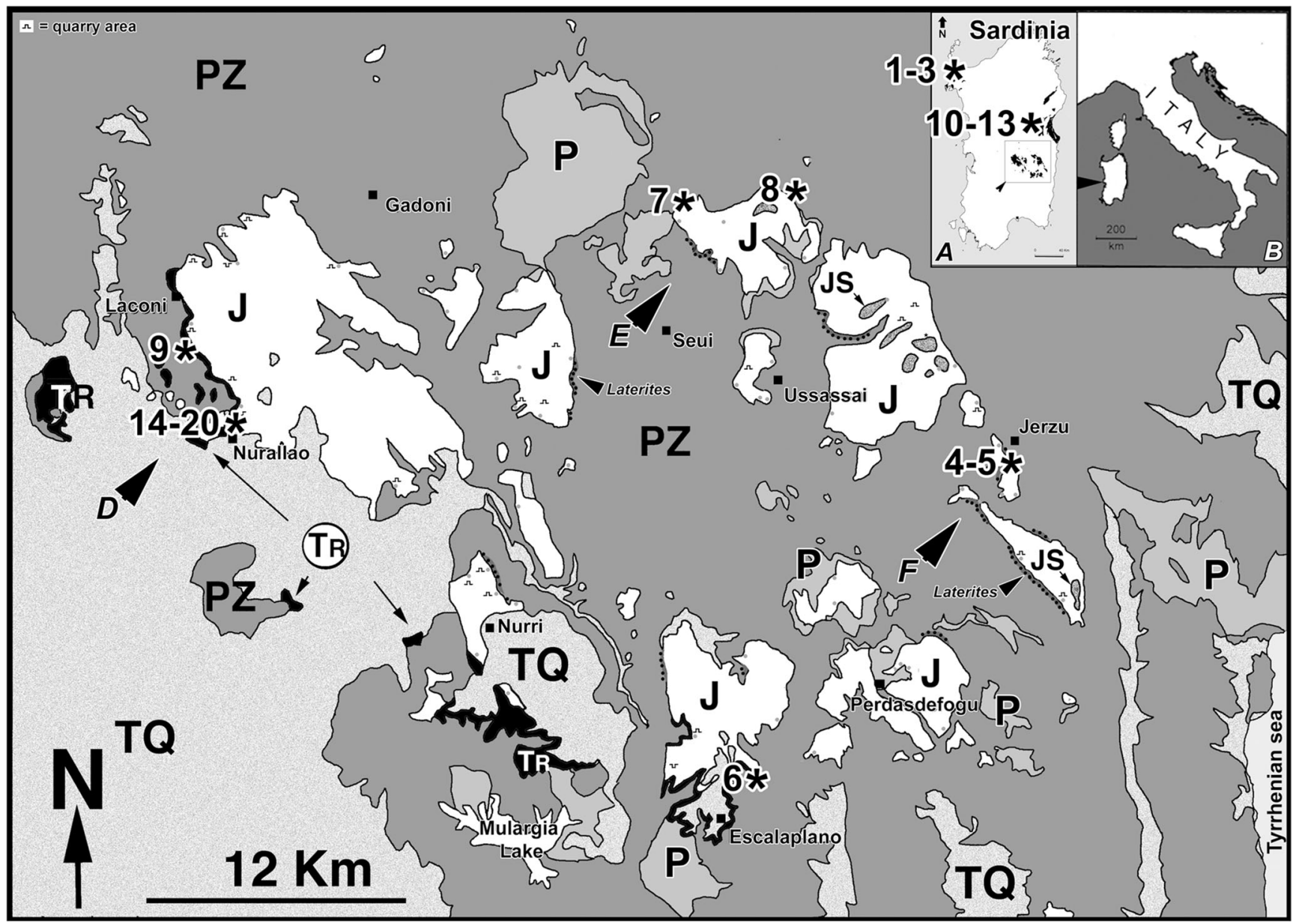

Fig. 1 Geological sketch map showing the location of the various Jurassic outcrops with palynogical analyses discussed in this paper. a Jurassic outcrops in Sardinia. b Location of Sardinia. c Geological sketch. PZ Variscan Basement, P Permian, TR Triassic, J Middle Jurassic, JS Middle-Late Jurassic, TQ Tertiary and Quaternary example, at Monte Rose (Fig. 2), the quarry front shows $90 \mathrm{~m}$ of Middle Jurassic oolitic limestones with intercalated blackish shales and grey marls (Ashraf et al. 1984; Del Rio 1990) so far not assigned to any stratigraphic unit. In Eastern Sardinia, samples have been collected from light grey sandy shales containing trunks (continental to transitional facies) or white sands with oxidised iron and lignite (lagoonal phases of freshwater to brackish environments) of the Genna Selole Formation (Ashraf et al. 1984; Del Rio 1976). The sections of central-eastern Sardinia incude the outcrops of Perdasdefogu, Tonneri Mt., Seui, Pala Asonis, Genna Su Ludu near Jerzu, Baunei, Escalaplano and Nuraghe Nieddu sensu Del Rio (1976), also known as Pitzu Rubiu Quarry. They are represented by black shales, white sandstones with iron oxide and lignite, limestone and marls (Del Rio 1976; Schneider 1978; Salard-Cheboldaeff in Dieni et al. 1983). The succession of the Pitzu Rubiu Quarry is divided into four horizons (Del Rio 1976) containing from bottom to top lightgrey sandy clay with fragments of lignitized trunks, light-grey sandy clay with sulphur, black shales rich in plant remains and just below the dolomitic rocks of the overlying formation, grey marls and black shales rich in plant remains. Additional six samples have been taken and processed from the two different rock types yielding plant fossils of collection A (numbers 21 and 22 in the paper); unfortunately, only the siltitic facies yielded palynomorphs. Slides are stored in the Museum of Geology and Paleontology "D. Lovisato" of Cagliari University.

Working on historical data does not permit to have the original counting for each sample. Since the main paper (Del Rio 1976) used classes of abundances, we applied this method but reduced the classes to four groups of frequency only: (i) present ( $\mathrm{P},<3 \%$ ), (ii) common $(\mathrm{C}, 4-7 \%)$, (iii) frequent ( $\mathrm{F}, 8-$ $11 \%)$, and (iv) abundant $(\mathrm{A},>12 \%)$. For comparison between macroremains and microremains, the botanical affinity of the sporomorphs was investigated and the relative abundances were compared (Schulz 1967; Balme 1995; Abbink 1998; Hubbard and Boulter 2000; Abbink et al. 2004; Herngreen 2005a, b; Raine et al. 2005; Barrón et al. 2006; Lindström and Erlström 2006; Ziaja 2006; Traverse 2007). 


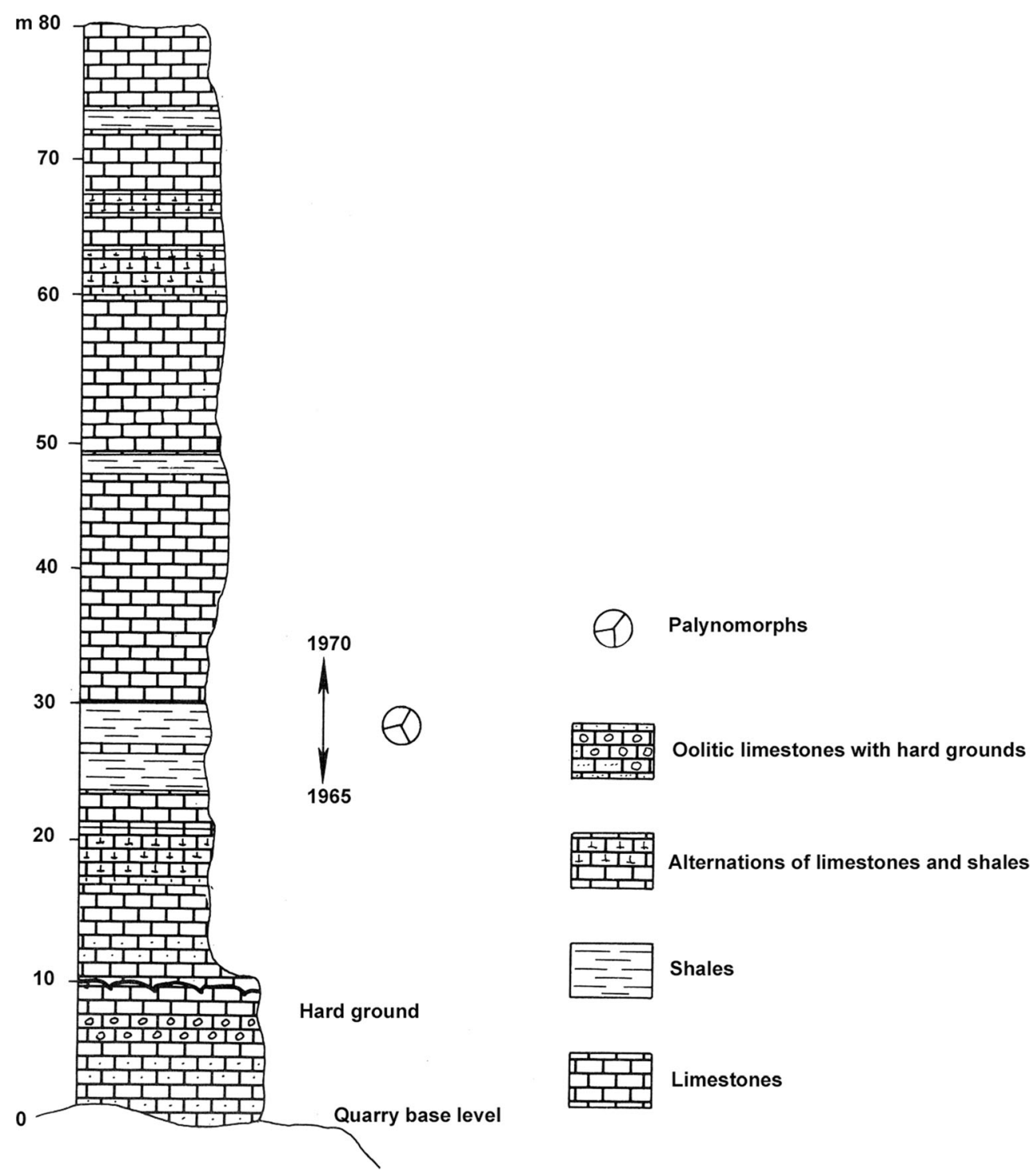

Fig. 2 Stratigraphy of the Monte Rosé Quarry with evidenced the sampled area (modified after Cherchi and Schroeder 1986)

In the last decades, many studies regarding palaeoenvironmental reconstructions have been performed, especially based on the palynoflora. Despite being slightly biased due to preservation, transport and sedimentation processes, spores and pollen (sporomorph) assemblages are still one of the most used and useful proxies for the reconstruction of the composition of terrestrial plant communities (Muller 1959; Chaloner and Muir 1968; Tyson 1995). The methods of Visscher and van der Zwan (1981), Abbink (1998) and Abbink et al. (2004), based on a quantitative analysis and grouping of the taxa into morphogroups (hygrophytic and xerophytic) or ecological categories (SEG), allow to interprete the palynological assemblages palaeogeographically, palaeoenvironmentally and palaeoclimatologically. The sporomorph ecogroup (SEG) model assumes that environmental variations such as temperature, water availability and sea-level changes are reflected in the composition of the SEGs
(Abbink 1998; Abbink et al. 2004) and can thus be deduced from the composition of the assemblage. The same method was applied here also for plant macrofossils, proposing a PEG.

\section{Geological setting and lithofacies of the Genna Selole Formation}

The Genna Selole Formation (Fig. 3) rests unconformably over metamorphic rocks of the Variscan basement (Carmignani et al. 1994) or, subordinately, over Permian (Cassinis and Ronchi 2002) or Triassic (Costamagna and Barca 2002) rocks. It is composed of siliciclastic to mixed siliciclastic-carbonate sediments deposited in a continental environment that evolves upwards to transitional and coastal sediments and finally tidally influenced lagoonal sediments (Costamagna and Barca 2004; Costamagna 2015). The thickness of the Genna Selole 


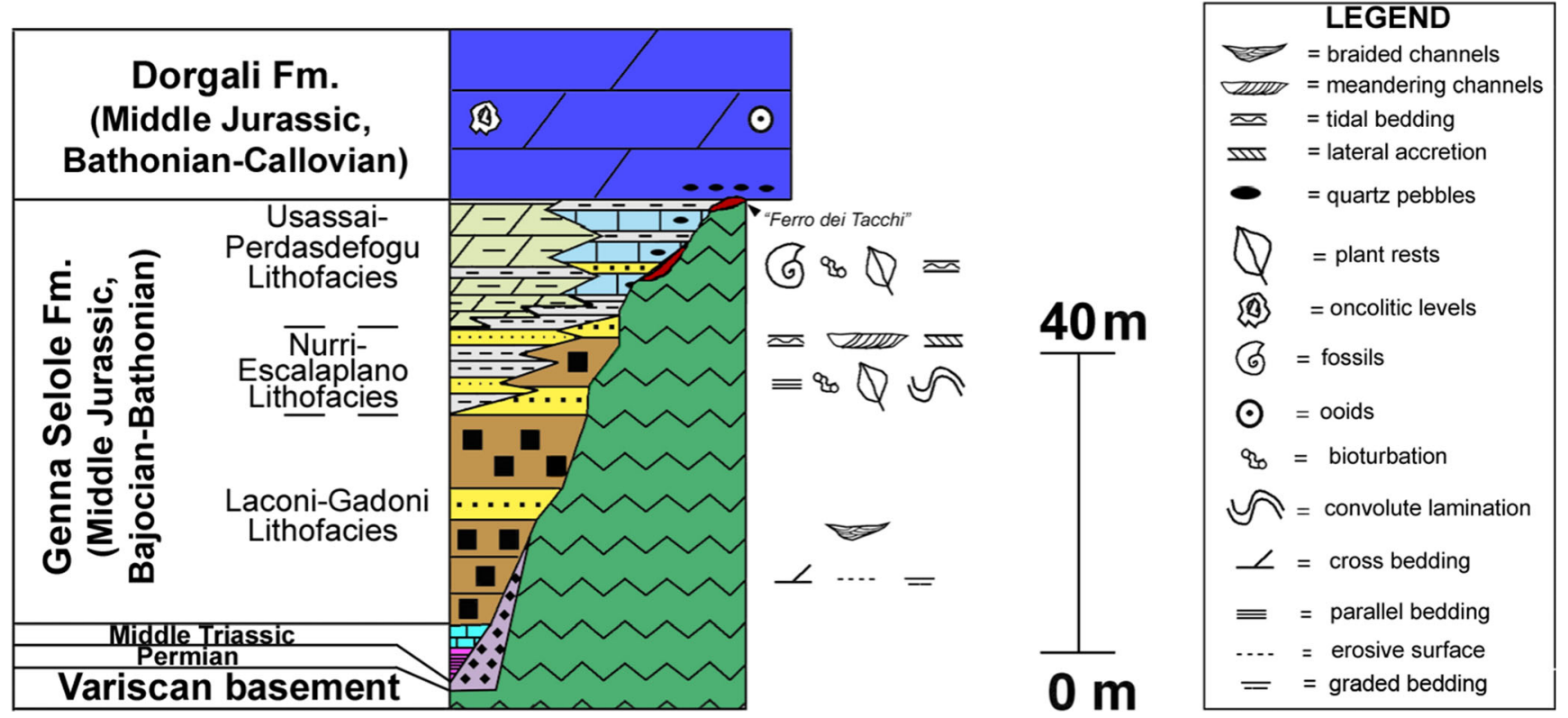

Fig. 3 General stratigraphic composition of the Genna Selole Formation (modified after Costamagna 2015)

Formation varies, depending on its geographical position (Dieni et al. 1983; Costamagna 2016). In the Tacchi area (Central Sardinia), it reaches up to $78 \mathrm{~m}$ in thickness but decreases northwards to a few metres in the Supramonte and Baronie area (NE Sardinia) and tends to disappear totally. The formation has been subdivided into three lithofacies (Costamagna and Barca 2004; Costamagna 2015), which are, from bottom to top, (1) Laconi-Gadoni conglomeraticarenaceous lithofacies, (2) Nurri-Escalaplano siltiticarenaceous-clayey-lignitiferous lithofacies, and (3) UssassaiPerdasdefogu mixed siliciclastic-carbonatic lithofacies. The lithofacies often do not crop out together in the various stratigraphic sections (Fig. 4). Moreover, they show an extremely variable thickness and are frequently heteropical. In some outcrops, alternations of the Laconi-Gadoni and Nurri-Escalaplano lithofacies have been noticed.

The Laconi-Gadoni lithofacies (0-35 m thick) is usually built of mature monomictic to oligomictic conglomerates containing lenses of quartzose to quartzose-feldspatic medium-grained to fine sandstones. This lithofacies tends to fine upwards, thus passing in the end to sandstones with rare conglomeratic lenses. Still, scattered pockets and sheets of finer deposits dark in colour with occasional wood fragments may be intercalated. The pebbles of the conglomerates are usually formed by quartz. Crude, parallel and tabular or through crossbedding are diffuse, as well as convolute laminations, graded bedding and erosive surfaces. Imbrications are scattered. In some fine-sized, whitish sandstone beds, rare plant fossils can be found. This lithofacies passes upwards gradually either to the other Genna Selole lithofacies, or directly, with the increase of the carbonate matrix, to the dolostones of the Dorgali Formation.
The Nurri-Escalaplano lithofacies reaches up to $12 \mathrm{~m}$ thickness. This lithofacies may locally overlie unconformably the Variscan basement without any coarser intercalation. This lithofacies is composed of alternations of blackish to whitish siltites, clayey siltites, lignitiferous siltites, clays and mediumgrained to fine sandstones, from well-stratified to thinly laminated. The sandstones may be lens-shaped and crossbedded, wavy and flaser bedding are diffuse. In finer lithologies, convolute laminations can be observed. Bioturbation is scattered. Fossil wood and other plant remains are found in the lignitiferous clays. The microfloristic assemblages found in this lithofacies suggest a Bajocian to Bajocian-Bathonian (Middle Jurassic) age (Del Rio 1976, 1984; Dieni et al. 1983). This lithofacies may pass directly upwards into the carbonate Dorgali Formation.

The Ussassai-Perdasdefogu lithofacies ranges from 1 to $35 \mathrm{~m}$ in thickness. This lithofacies varies noticeably depending on its location. It may be formed by marly dolostones containing scattered centimetre-thick siltitic and fine sandy terrigenous beds, or by alternations of limestones, dolomitic limestones, marls and plant-rich, fine- to medium-sized siliciclastics sometimes lens-shaped. Close to the boundary with the upper Dorgali Formation, centimetre-sized beds of black siltites with scattered plant fossils are diffuse. The boundary with the Dorgali Formation is defined by the disappearance of the terrigenous content in the carbonate sediments. The carbonates of this lithofacies are fossiliferous and cross-bedded; lenticular, wavy, and flaser bedding has been observed. Dieni et al. (1983) attributed this lithofacies to the Bathonian, based on its palaeontological content. Close to the top often firm- and hard-ground surfaces occur partially bioturbated and/or bio-eroded; thin oxidised crusts and early 


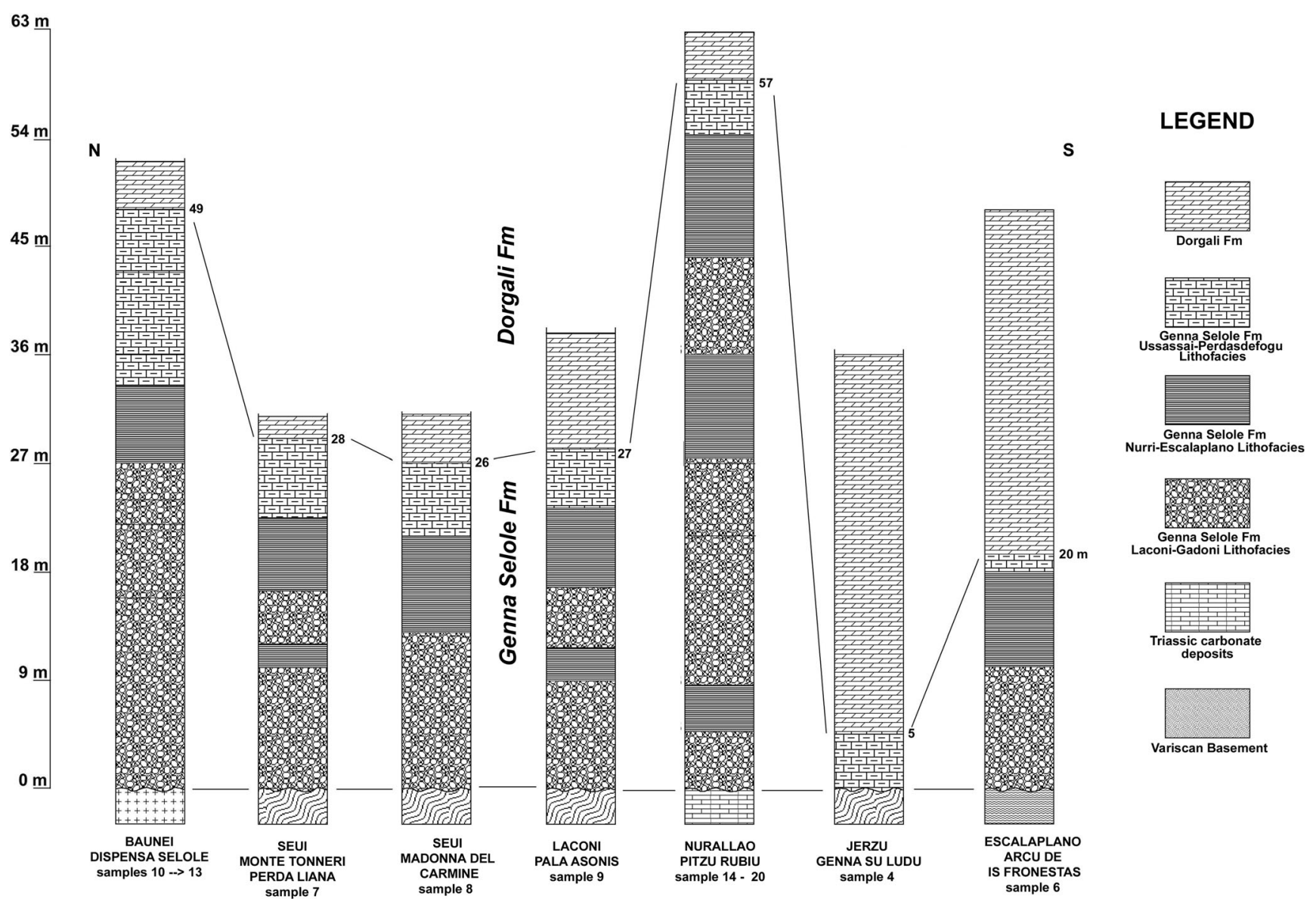

Fig. 4 Stratigraphic columns of the main Eastern Sardinia Jurassic outcrops showing how the thickness of the three lithofacies of the Genna Selole Fm varies geographically

karstic phenomena developed at several levels over the carbonates. These data evidence limited and short-lasting regressive events during the evolving Middle Jurassic transgression (Costamagna et al. 2007; Costamagna 2015). Evidences of synsedimentary tectonics in the Genna Selole Formation are related to extensional movements.

Genna Selole Formation: facies interpretation and depositional environments

The Genna Selole Formation was deposited within an active extensional tectonic regime under a warm and humid climate (Costamagna 2015), possibly related with the early Middle Jurassic Tethys opening. It documents the formation of a main tectonic high later fragmented into several minor highs and culminates with their final transgression. A narrow continental to transitional shallow marine depositional system was formed along the slopes of the tectonic highs (coastal wetland sensu Suárez-González et al. 2015). The high-gradient palaeoslopes eroded filling the marginal depositional environments. Here, alluvial fan and braided stream environments (Laconi-Gadoni lithofacies) passed rapidly seaward and laterally first into an alluvial-palustrine-littoral belt containing brackish ponds, salt marshes and perhaps small-scale delta bodies (NurriEscalaplano lithofacies), and finally to mixed carbonatesiliciclastic lagoonal-shallow marine deposits (UssassaiPerdasdefogu lithofacies). The fans were crossed by braided channels. The coastal plain was frequently waterlogged and crossed by migrating, meandering sandy channels. The plain was colonised by warm and humid, possibly tropical vegetation associated with significant seasonal rainfall (Del Rio 1976, 1984; Scanu et al. 2012).

The alluvial fans were probably located at the outlet of palaeovalleys, locally passing to braided deltas close to the sea, while the alluvial-palustrine-littoral belt was likely located in coastal areas between the valley outlets. In the outer part of this belt, tidal influence is observed. The distal fan and the coastal plain deposits interfingered proximally and laterally due to fluctuations perhaps related to minor relative sea-level changes, tectonic movements or changes in sediment supply. The progressive disappearance of tide-generated features, the thinning of the Genna Selole Formation, and the gradual replacement of fluvial terrigenous debris by marine, highenergy carbonate deposits, represents a proximal-distal variation of Ussassai-Perdasdefogu lithofacies, and the gradual passage into the dolostones of the Dorgali Formation that still 
contains scattered quartz pebbles. The environment was tidally influenced with synsedimentary tectonism triggering periodic emersion. With the progressive transgression of the high, the lower Laconi-Gadoni and Nurri-Escalaplano lithofacies of the Genna Selole Formation disappear, and the UssassaiPerdasdefogu lithofacies rests directly over the Variscan basement. In rare cases, this latter lithofacies is not observed and the basement is overlain by the Dorgali Formation rich in quartz pebbles.

\section{The macroflora}

Composition of the Middle Jurassic flora of Sardinia

The Jurassic fossil flora consists of more than 700 rock slabs with vegetative shoots and leaves, reproductive organs and dispersed seeds. Plant fossils are preserved as impressions and compressions, in some cases cuticles and in situ spores are preserved as well. The plant fossils can be attributed to 44 taxa belonging to the horsetails, ferns, seed ferns, Cycadales, Bennettitales, putative ginkgophytes, Czekanowskiales and conifers (Scanu et al. 2015, 2016; Kustatscher et al. 2016). Only lycophytes and bryophytes have not been found as macroremains, but are documented by palynomorphs.

Horsetails are represented as decorticated stem fragments and diaphragms (Kustatscher et al. 2016) and based on their dimensions can be subdivided into Equisetites beani (Bunbury) Seward, 1894 and E. columnaris (Brongniart) Phillips, 1875 (Fig. 5a). A nodal fragment with microphylls of Schizoneura Schimper et Mougeot, 1844 is also present (Kustatscher et al. 2016). Strobilus fragments are oblong, up to $15 \mathrm{~mm}$ long and $5 \mathrm{~mm}$ wide with irregularly square to rhombic $(1-1.5 \mathrm{~mm}$ in diameter) sporophyll heads (Scanu et al. 2016). Ferns (Fig. 5bg) are common with Dicksoniaceae as the most diversified family (three genera; Scanu et al. 2015, 2016). They are represented by Coniopteris sp. cf. C. hymenophylloides (Brongniart) Seward, 1900 emend. Harris, 1961, characterised by the large, lanceolate pinnules with a more or less narrow base that are attached at an angle of $70-80^{\circ}$ to the rachis (Fig. 5c). In Dicksonia kendallii Harris, 1961 (Fig. 5f), the margin of the pinnules is more entire compared to the bigger pinnules of Eboracia sp. cf. Eboracia lobifolia (Phillips) Thomas, 1911 emend. Harris, 1961 (Fig. 5e). The latter is represented by lanceolate to spatulate pinnules $(5 \times 3 \mathrm{~mm})$ with an entire margin and a rounded to slightly pointed apex (Scanu et al. 2016).

Matoniaceae are constituted by four taxa. The species Phlebopteris polypoidioides Brongniart, 1828 (Fig. 5d), Phlebopteris dunkeri (Schenk) Schenk, 1875, Phlebopteris muensteri (Schenk) Hirmer and Hörhammer, 1936 and Phlebopteris braunii (Göppert) Harris, 1980 differ from each other in venation type, shape and size of the pinnules. In $P$. polypoidioides and P. muensteri, the pinnules are elongate to lanceolate with a rounded apex and an entire margin, whereas P. braunii has relatively narrow pinnules (Fig. 5b). Moreover, in P. muensteri, the pinnules are basally connected by an extension of the lamina, creating a kind of wing (Scanu et al. 2015, 2016). Phlebopteris dunkeri is represented by small fragments with distinct anastomosing venation and a fusain-like preservation. Marattia intermedia (Münster) Kilpper, 1964 is the only representative of the Marattiaceae. This species is characterised by pinnae with an entire margin; the synangia occupy the outermost third to half of the lamina (Fig. 5b). Only one specimen of Hausmannia crenata (Nathorst) Moeller, 1902 belongs to the Dipteridaceae (Fig. $5 \mathrm{~g}$ ). It has a wedge-shaped frond shape and the squared mesh pattern of the venations. The Osmundaceae include Todites williamsonii (Brongniart) Seward, 1900 emend. Harris, 1961, Cladophlebis sp. cf. C. denticulata (Brongniart) Fontaine, 1889 and small fragments attributed to Cladophlebis sp. Todites williamsonii is characterised by falcate to lanceolate pinnules with a slightly rounded apex, a broad basis and an entire margin. Cladophlebis denticulata differs from the latter because of the denticulate margin of the pinnules and its venation.

Seed ferns are rare in the flora. They include leaf fragments of Ctenozamites sp., isolated lanceolate leaflets with a rounded apex and a marked midrib belonging to Sagenopteris phillipsii (Brongniart) Presl in Sternberg, 1838 and probably a fragment of a Caytonia-type of reproductive organ. The latter is now missing in the collection but documented in Edwards (1929). Leaves of Eretmophyllum lovisatoi Edwards, 1929 (Fig. 6e) may represent the only putative ginkgophyte of the flora. Czekanowskia sp. cf. Czekanowskia furcula Harris et Miller, 1974 in Harris et al. (1974) is the only czekanowkialean taxon in the flora. These plants had elongated leaves that dichotomize once, and they have a thick cuticle with isodiametric epidermal cells that become more elongated near the margin of the leaf.

The cycadophytes are the most important group both in species diversity and relative abundance (Scanu et al. 2015). To the Cycadales belong Nilssonia sp. cf. N. orientalis Heer, 1878 with its linear-shaped leaf segments with an entire margin and unforked, parallel secondary veins, and some leaf fragments attributed only to the genus Nilssonia Brongniart, 1925. Cycadeospermum lovisatoi Krasser, 1912 (Fig. 6c) has rounded seeds with a characteristic verrucate structure; it could belong to Nilssonia (Gothan 1914; Edwards 1929). The Bennettitales are much more diverse. Leaf fragments belonging to Ptilophyllum Morris in Grant, 1840 are represented by three species, Ptilophyllum pectinoides (Phillips) Halle, 1913 (Fig. 6a), Ptilophyllum cariae Scanu et al., 2015 and Ptilophyllum sp. cf. Pt. hirsutum Thomas and Bancroft ex Harris, 1949 (Dieni et al. 1983). The first two species are macromorphologically similar with narrow, elongate segments, but can easily be distinguished based on the cuticle. In $P$. pectinoides the anticlinal walls of the epidermal cells of both the upper and lower lamina are undulated, in Ptilophyllum cariae 
the anticlinal walls of the upper lamina are straight and only those of the lower lamina undulated. The segments of Ptilophyllum sp. cf. $P$. hirsutum are broader with distinct, parallel veins and strongly undulating anticlinal walls of the epidermal cells of both laminae. The reproductive organs Williamsonia hildae Harris, 1969 (female) and the microsporangiate reproductive organ Weltrichia sp. cf. W. whitbiensis (Nathorst) Harris, 1969 (male; Fig. 6b) are also present in the collections and are considered to belong to Ptilophyllum pectinoides. Additional reproductive organs have been assigned to Weltrichia sp. and Cycadolepis sp. Otozamites veronensis De Zigno, 1881 is missing from the collections but its former presence is demonstrated by illustrations (Kustatscher et al. 2016).

The conifers are represented by different shoot types, including at least two species of Brachyphyllum Brongniart, 1828 emend. Harris, 1979, i.e. Brachyphyllum expansum (Presl in Sternberg) Seward, 1919 emend. Kendall, 1949 (Fig. 6d) and Brachypyllum sp. The former has scale-like leaves inserted on the axis in a close helix and a thick, amphistomatic cuticle with isodiametric epidermal cells and straight anticlinal walls. The scale-like rhombohedral leaves with rounded apex of Brachypyllum sp. have only one vein. Cuticles are thick; the isodiametric epidermal cells are disposed in regular rows on both sides of the leaf. Geinitzia divaricata (Bunbury) Harris, 1979 has small, falcate leaves with a thin and fragile cuticle, whereas the elongated leaves of Elatocladus Halle, 1913 emend. Harris, 1979 have a slightly pointed apex and are arranged in a large spiral. Shoots of Elatides williamsonii (Lindley et Hutton) Nathorst, 1897 and Pagiophyllum sp. compose the rest of the coniferous flora. Ovuliferous scales are assigned to Araucarites sardinicus (Krasser) Krasser, 1920, whereas wood fragments have been assigned to Agathoxylon sp.

Of unknown botanical affinity are the seed types Carpolithes sp. 1 sensu Scanu et al., 2015 and Carpolithes sp. 2 sensu Scanu et al., 2015 (Fig. 6g) that differ in their shape and dimensions. The former is oval in shape with elongated costae and a concave structure with a rim. The latter is rounded with longitudinal striae crossing the entire length; sometimes the seeds are divided into two hemispheres. Taeniopteris Brongniart, 1828 specimens are also of uncertain botanical affinity, perhaps belonging to the cycadophytes. Its leaf fragments show badly preserved parallel veins. The stem fragment Sardoa robitschekii Krasser, 1290 may belong to the Bennettitales.

In terms of number of fossil taxa the composition of the three collections differs noticeably. Lovisato A collection in Cagliari is the most abundant with 24 different taxa. The most abundant groups are cycadophytes (29\%) and ferns (25\%), conifers are common (16\%), horsetails and Czekanowskiales rare (1 fossil taxon each: 4\%) whereas ginkgophytes are absent. The Lovisato B collection in Prague is composed of 23 fossil taxa with the conifers as the most diverse plant group (30\%), followed by cycadophytes and ferns (four taxa each; $17 \%$ ). Horsetails are common (three fossil taxa), whereas
Fig. 5 Selected horsetails and ferns from the Middle Jurassic of Sardinia. a Equisetites columnaris (Brongniart) Phillips, 1875 (Lov. B 2, Prague). b Marattia intermedia (Münster) Kilpper, 1964 (left) and Phlebopteris braunii (Göppert) Harris, 1980 (MSNVE 23398, Venice). c Coniopteris sp. cf. C. hymenophylloides (Brongniart) Seward, 1900 emend. Harris, 1961 (MGPDL 9032, Cagliari). d Phlebopteris polypoidioides Brongniart, 1836 (MGPDL 9415, Cagliari). e Eboracia lobifolia (Phillips) Thomas, 1911 emend. Harris, 1961 (MSNVE 20423-4, Venice). f Dicksonia kendallii Harris, 1961 (MSNVE 20423-1, Venice). g Hausmannia crenata (Nathorst) Moeller, 1902 (MGPDL9415, Cagliari)

Czekanowskiales are missing in the Lovisato B collection. The Miccolis collection is the least diverse plant assemblage, with only 11 fossil taxa. The most abundant are the ferns (64\%), while seed ferns, ginkgophytes and Czekanowskiales are absent. The specimens of the Miccolis collection are well preserved and beautiful, typical for a fossil collector (Scanu et al. 2016). The total flora based on the three collections together, in number of species is composed mostly of ferns (33\%), followed by cycadophytes (26\%) and conifers (15\%).

Relative abundances in the two lithofacies of the macroflora

The macrofossils found in the different collections are preserved on rather similar lithologies suggesting that the samples come from similar stratigraphic horizons and/or were deposited under the same/similar environmental conditions. A collecting bias can obviously not be excluded, but the presence of small and poorly preserved fragments together with the well-preserved remains suggests that the human selection was perhaps not too high. Only in collection A two different lithofacies can be distinguished. Lithofacies 1 corresponds to a mixed medium-fine and fine sandstone ( $64 \%$ of all samples), whereas lithofacies 2 corresponds to siltstone (36\%). The plant remains were distinguished based on their lithology, and for each group, a detailed quantitative analysis was carried out.

The more coarse-grained lithofacies 1 (Fig. 7; Table 2) is dominated by the genus Ptilophyllum (46\%), followed by Coniopteris (20\%), Phlebopteris (6\%), Nilssonia and Carpolithes (4\%). Occasionally, Brachyphyllum, Cycadeospermum (2\%), Todites, sphenophytes and Czekanowskia (1\%) are present. Rare are Cladophlebis, Geinitzia, Ctenozamites, Weltrichia and Williamsonia $(<1 \%)$. Elatocladus, Hausmannia, Sagenopteris and Taeniopteris are so far missing in the sandy lithology, whereas indeterminable plant remains are common (10\%), related probably to the poor preservation potential of this sediment. The frequent presence of charcoal (8\%) could suggest that the vegetation was still luscious and wildfire occurred occasionally in the forests. Ptilophyllum (40\%) and Coniopteris (15\%) are also the most abundant genera in lithofacies 2, suggesting that they were prominent elements of the Middle Jurassic flora of Sardinia (Fig. 7; Table 2). Lithofacies 2 includes frequent Carpolithes (9\%), Nilssonia, Phlebopteris (5\%), occasional Czekanowskia 

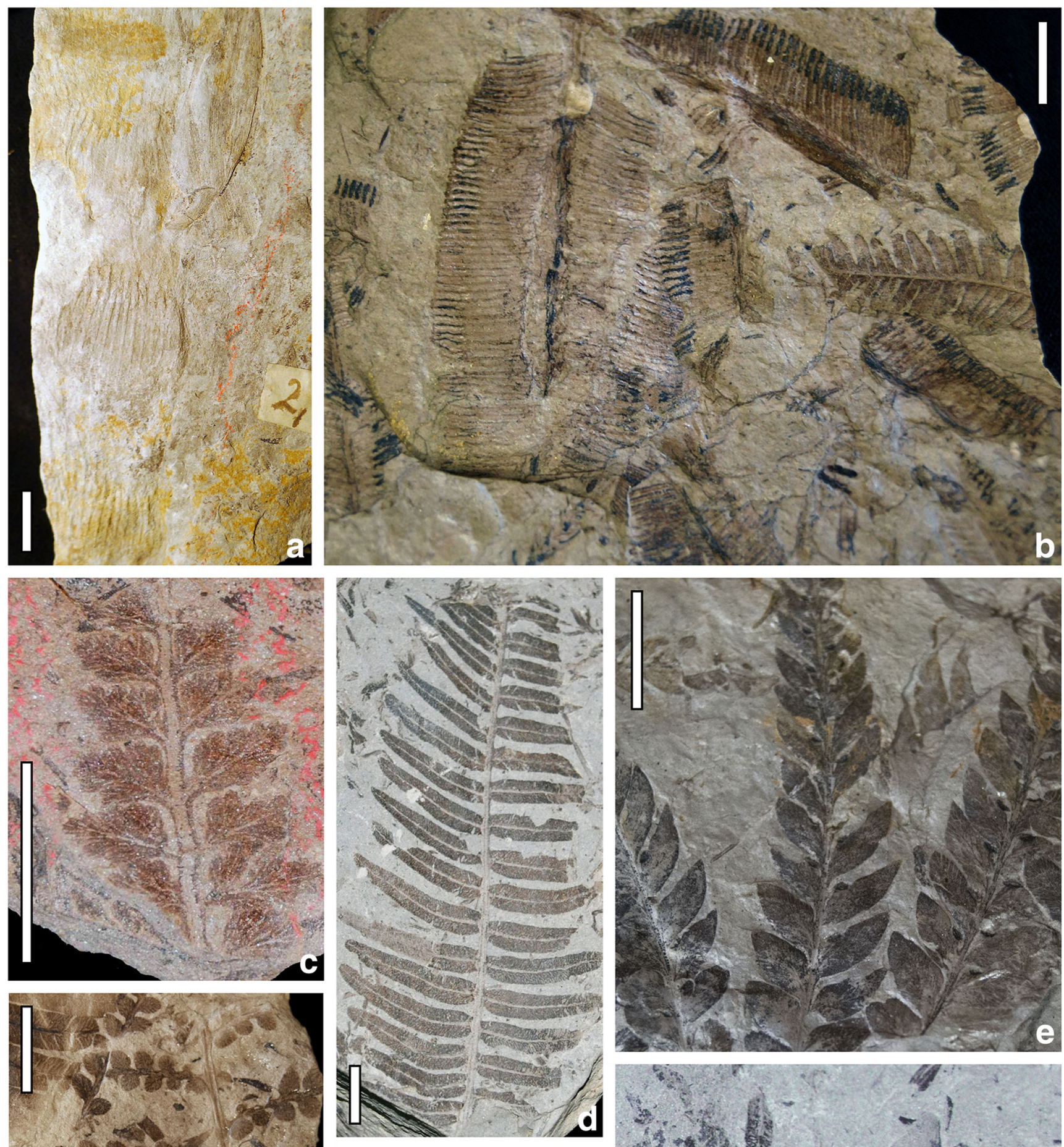

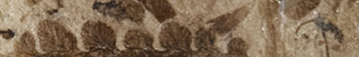
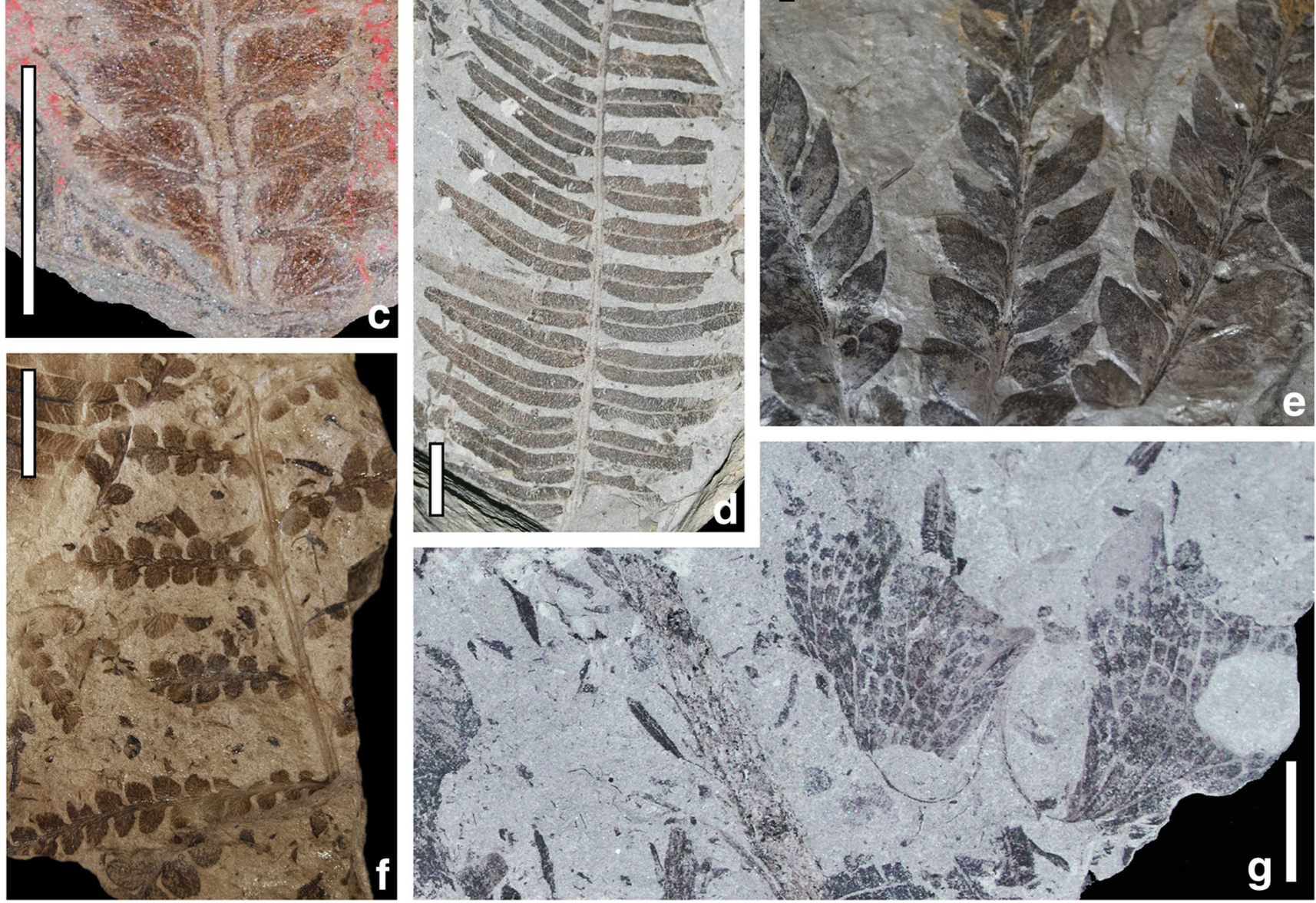

weth

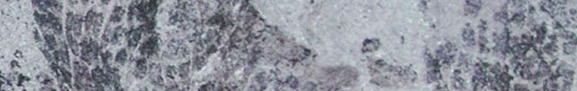


(4\%), Todites (3\%), Geinitzia (2\%), Cycadeospermum, Brachyphyllum, Cladophlebis and sphenophytes (1\%). Hausmannia, Elatocladus, Pterophyllum, Ctenozamites, Sagenopteris, Taeniopteris, Weltrichia and Williamsonia are rare $(<1 \%)$. Undetermined fragments are common $(11 \%)$, and charcoal is frequent also in this lithofacies $(9 \%)$.

The most representative taxa (Ptilophyllum, Coniopteris, Phlebopteris, Nilssonia and Carpolithes) are the same in both lithofacies, and only the rare elements in the fine-grained lithology 2 are missing in the coarse-grained lithology 1 . If we consider the higher groups (Tables 1 and 2), the cycadophytes are the most abundant groups (respectively 53 and $46 \%$ in the two lithologies) in both lithofacies, followed by the ferns (respectively 27 and 25\%), whereas the other groups are rare (>3\%). Moreover, the plant fragments are generally highly fragmented, suggesting that the material was subjected to a substantial transport before deposition. This suggests that the difference in composition may be related more to taphonomic selection and preservation bias than to differences in the general composition of the flora. However, it cannot completely be excluded that the different composition of the two lithofacies may reflect also slight habitat differences.

Plant fossils and their palaeoecology

The sphenophytes are considered restricted to humid environments due to their need of water during the reproductive cycle. Barbacka $(2009,2011)$ suggested that Equisetites grew in wetter areas, together with Elatocladus, a conifer adapted to more humid environments (see also below), but attributed the species Equisetites columnaris to the Ptilozamites (Ctenozamites) ecogroup, which characterised the moderately wet canopy. We consider Equisetites to belong to the wet environments near water bodies.

Ferns prefer generally shady, humid and temperate to warm environments although not all taxa were restricted to such conditions (e.g. Abbink et al. 2004; Van Konijnenburg-van Cittert 2002). The Marattiales (e.g. Marattia) grew under warm and humid climate in the understorey of a floodplain environment. During the Jurassic, Osmundaceae preferred probably warm and humid environments, such as riverbanks, lake shores or freshwater marshes, where they formed peat, or brackish-water environments near the sea coast (e.g. Vakhrameev 1991; Wang 2002; Van Konijnenburg-van Cittert 2002; Barbacka and Bodor 2008). Cladophlebis denticulata and Todites williamsonii formed monospecific assemblages with in situ trunks on the edges of the marshes in the Lower Jurassic of Romania (Popa 2000; Van Konijnenburg-van Cittert 2002) but extended its niches also towards dry and disturbed conditions (e.g. Harris 1961; Van Konijnenburg-van Cittert and van der Burgh 1996; Popa and Meller 2009; Barbacka 2011). Matoniaceae grew during Jurassic times under humid conditions in the understorey or
Fig. 6 Selected bennettitales, gingkophytes, conifers, seeds and branchiosaurids from the Middle Jurassic of Sardinia. a Ptilophyllum pectinoides (Phillips) Halle, 1913 (MGPDL 246, Cagliari). b Weltrichia sp. cf. W. whitbiensis (Nathorst) Harris, 1969 (MSNVE20423-5, Venice). c Cycadeospermum lovisatoi Krasser, 1912 (MGPDL 9050, Cagliari). d Brachyphyllum expansum (Presl in Sternberg) Seward, 1919 emend. Kendall, 1949 (MSNVE 23393, Venice). e Eretmophyllum lovisatoi Edwards, 1929 (Lov. B 66, Prague). f Estheria sp. (Lov. B 98, Prague). g Carpolithes sp. 2 (MGPDL 9442, Cagliari)

along riverbanks, although some forms were more stressadapted (Phlebopteris, Van Konijnenburg-van Cittert 2002); we attribute it to the wet lowland. Mesozoic Dicksoniaceae, such as Coniopteris, Dicksonia and Eboracia, were small herbaceous plants with creeping rhizomes (Van Konijnenburgvan Cittert 2002; Wang 2002; Deng and Lu 2006) living in the humid understorey of the lowland. Dipteridaceae (e.g. Hausmannia) were during the Mesozoic opportunistic plants that colonised disturbed habitats (Cleal and Rees 2003) such as stream sites, riverbanks and exposed ridges and clearings (Cantrill 1995; Van Konijnenburg-van Cittert 2002).

Seed ferns like Caytoniales reached a peak of development during the Jurassic. These plants, represented here by Sagenopteris, were part of the moist lush vegetation in deltaic environments during warm Jurassic and Cretaceous times (Harris 1964; Van Konijnenburg-van Cittert and Van der Burgh 1989), or grew, together with conifers, at the margin of the swamps (Popa 1997; Popa and Van Konijnenburg-van Cittert 2006). We assign it in our flora to the moderately disturbed and relatively dry lowland areas (Kustatscher et al. 2010) that were high enough not to be flooded (Sagenopteris ecogroup; Barbacka 2011). The fact that its leaves are covered by thin cuticles could suggest that the plant grew as a shrub or small tree in more shaded places with high air humidity of the understorey (Harris 1964, Gordenko 2008). Ctenozamites, on the other hand, shows xeromorphic features (coriaceous leaves, small pinnules, protected stomata, thick cuticles), that position the taxon in drier areas and/or in a seasonally or periodically dry climate (Rees et al. 2000; Hesselbo et al. 2003). Barbacka (2011) attributed it to the weakly disturbed, moderately wet canopy covered by the Ptilozamites (Ctenozamites) ecogroup, together with other genera such as Equisetites and Phlebopteris.

Both Eretmophyllum (a putative gingkophyte) and Czekanowskia (Czekanowskiales) are characterised by thin and brittle cuticles suggesting a humid environment similar to extant Ginkgo and fossil ginkgophytes. Zhou (2009) suggested that Mesozoic ginkgophytes preferred stable and ecologically saturated conditions. In the Jurassic of Hungary ginkgophytes (although with different genera) were predominantly represented in weakly disturbed wetlands (Ginkgoites ecogroup; Barbacka 2011), but they could colonise both wet and dry environments and also the upland forests (Van 

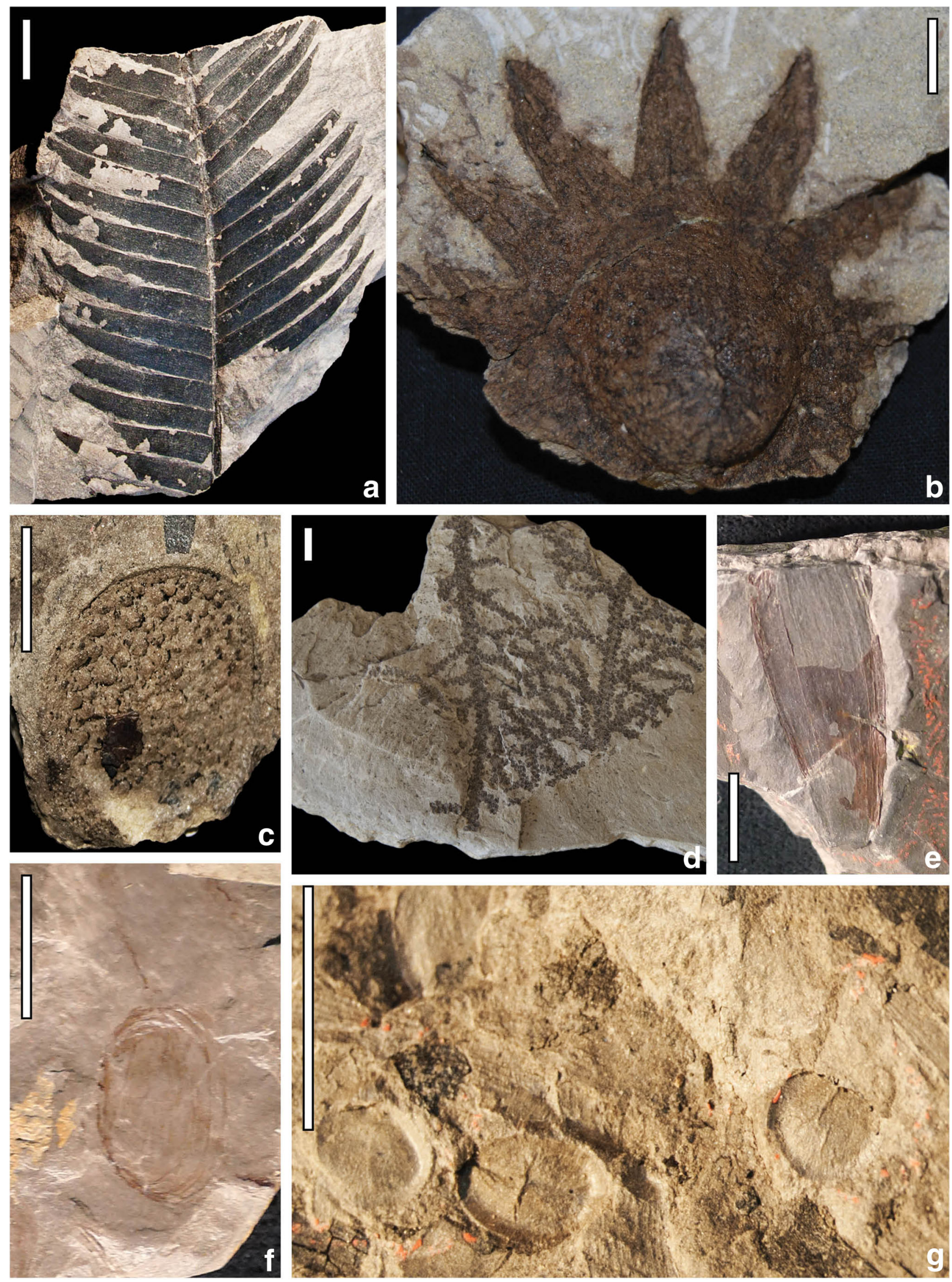


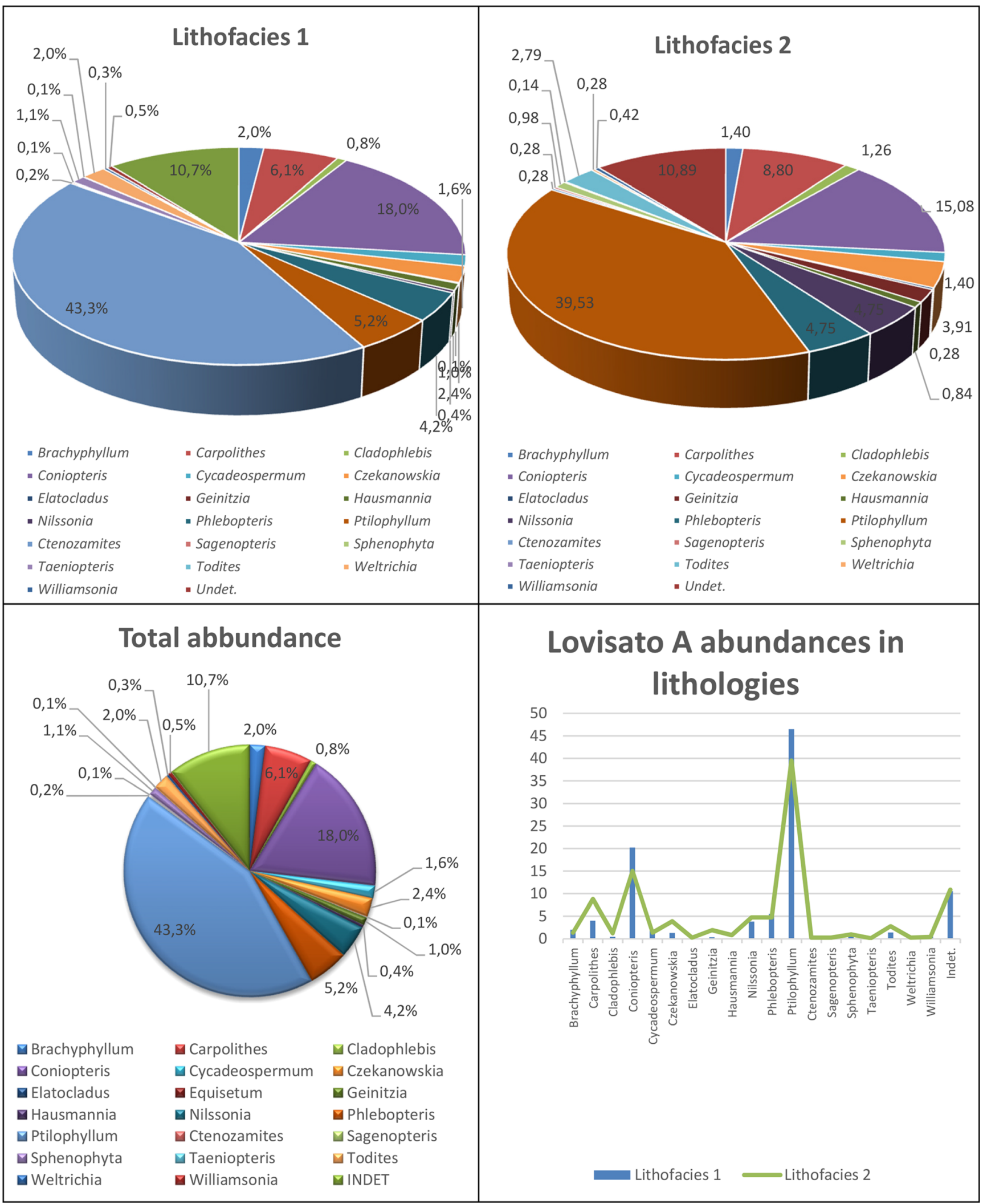

Fig. 7 Relative abundances of the genera in the two different lithofacies

Konijnenburg-van Cittert and van der Burgh 1996; Popa and van Konijnenburg-van Cittert 2006). Czekanowskiales are reconstructed as deciduous trees or shrubs growing on the sloping fields along the meandering rivers, lakes and swamps 
Table 1 Overview of the main plant macroremain genera of the Jurassic flora of Sardinia and their attribution to the higher plant groups and the various plant ecogroups

\begin{tabular}{lll}
\hline & Plant group & Plant ecogroup \\
\hline Brachyphllum & Coniferophytes & Coastal PEG \\
Carpolithes & Indet. & Indet. \\
Cladophlebis & Ferns & Humid Lowland PEG \\
Coniopteris & Ferns & Humid Lowland PEG \\
Cycadeospermum & Cycadophytes & Drier Lowland PEG \\
Czekanowskia & Czekanowksiales & River PEG \\
Elatocladus & Coniferophytes & River PEG \\
Geinitzia & Coniferophytes & Drier Lowland PEG \\
Hausmannia & Ferns & River PEG \\
Nilssonia & Cycadophytes & Drier Lowland PEG \\
Phlebopteris & Ferns & Drier Lowland PEG \\
Ptilophyllum & Cycadophytes & Drier Lowland PEG \\
Ctenozamites & Seed ferns & Drier Lowland PEG \\
Sagenopteris & Seed ferns & Drier Lowland PEG \\
Sphenophyta & Sphenophytes & River PEG \\
Taeniopteris & Cycadophytes & Drier Lowland PEG \\
Todites & Ferns & Humid Lowland PEG \\
Weltrichia & Cycadophytes & Drier Lowland PEG \\
Williamsonia & Cycadophytes & Drier Lowland PEG \\
Indet. & Indet. & Indet. \\
\hline & &
\end{tabular}

(Sun et al. 2015), extending from tropical regions near the Tethys to the temperate regions of Siberia (Vakhrameev et al. 1970) with Czekanowskia being more common at higher latitudes (Samylina and Kiritchkova 1993).

Cycadales (Nilssoniaceae) grew during the Mesozoic as lowland plants in subtropical areas with warm climate or co-occurred with ginkgophytes and conifers in open forests (Batten 1974; Van Konijnenburg-van Cittert and Van der Burgh 1989; Vakhrameev 1991; Kustatscher et al. 2010). In the Jurassic of Romania, they were found growing in the final phase of the peat swamp development
(Popa and van Konijnenburg-van Cittert 2006). Nilssonia was part of moderately disturbed, relatively dry (nonflooded) lowland areas (Sagenopteris ecogroup: Barbacka 2011) but could also be adapted to more humid swamp-lake environments. Bennettitales were interpreted as growing under warm and subtropical conditions (Vakhrameev 1991). They are considered coal generators although they were not swamp dwellers since the manoxylic wood of bennettitaleans would decay quickly in water-dominated environments. The plants preferred drier habitats, such as flood plains or the margins of closing marsh areas when these were almost filled-up with sediments (Popa 1989, 2014) or even dry-savannah vegetation under arid conditions (Diéguez et al. 2009). The Ptilophyllum leaves of the Middle Jurassic of Sardinia show xeromorphic characters with cuticles protected heavily by papillae and sunken stomata.

Mesozoic conifers inhabited relatively drained and dry slopes of upland forests (Vakhrameev et al. 1970; Batten 1974; Vakhrameev 1991; Wang et al. 2005; Falcon-Lang et al. 2009; Kustatscher et al. 2010). However, not all conifers were restricted to the drier habitats. Elatocladus grew, together with sphenophytes, in shallow water along river or lake banks or in swamps (Barbacka 2009, 2011). The xeromorphic features of the Cheirolepidiaceae are attributed to physiological dryness and adaptation to stressed environments such as coastal environments rather than dry climates (e.g. Batten 1974; Nguyen Tu et al. 1999; Nilssonia ecogroup: Barbacka 2011; Barbacka et al. 2014); they are also indicators of high annual temperature although Tosolini et al. (2015) evidenced that they may have a broad range of habitats from low-latitude arid to coastal to humid high-latitudes during the Cretaceous. Brachyphyllum is very abundant in the Jurassic floras of Europe, probably due to its wide environmental tolerance (Vakhrameev 1970, 1991; Alvin 1982; Van Konijnenburgvan Cittert and van der Burgh 1996; Hesselbo et al. 2003; Wang et al. 2005; Greb et al. 2006; Popa and Van Konijnenburg-van Cittert 2006; Barbacka et al. 2014). The Sardinian Brachyphyllum species evidence several xero-
Table 2 Relative abundance of the macroremains assemblages (lithofacies 1, lithofacies 2) and the palynological assemblages $(21,22)$ considering the higher plant groups

\begin{tabular}{|c|c|c|c|c|c|c|}
\hline & \multicolumn{3}{|l|}{ Macroremains } & \multicolumn{3}{|c|}{ Palynological samples } \\
\hline & Lithofacies $1(\%)$ & Lithofacies $2(\%)$ & Mean $(\%)$ & $21(\%)$ & $22(\%)$ & Mean $(\%)$ \\
\hline Bryophytes & 0.00 & 0.00 & 0.00 & 2.11 & 2.22 & 2.16 \\
\hline Lycophytes & 0.00 & 0.00 & 0.00 & 9.47 & 10.00 & 9.74 \\
\hline Sphenophytes & 1.28 & 0.98 & 1.13 & 1.05 & 1.11 & 1.08 \\
\hline Ferns & 27.52 & 24.72 & 26.12 & 54.74 & 46.67 & 50.70 \\
\hline Seed ferns & 0.11 & 0.56 & 0.33 & 5.26 & 5.56 & 5.41 \\
\hline Czekanowksiales & 1.28 & 3.91 & 2.59 & 0.00 & 0.00 & 0.00 \\
\hline Cycadophytes & 52.92 & 46.51 & 49.72 & 1.05 & 4.44 & 2.75 \\
\hline Coniferophytes & 2.34 & 3.63 & 2.98 & 24.21 & 27.78 & 25.99 \\
\hline Indet. & 14.56 & 19.69 & 17.13 & 2.11 & 2.22 & 2.16 \\
\hline
\end{tabular}


morphic features such as small leaves strongly appressed to the shoots, thick cuticles with sunken stomata and epidermal cells protected by papillae, supporting a stressed and/or dry environment (Thevenard et al. 2005). The fossil genus Brachyphyllum comprises conifers that belong to the Araucariaceae, Cheirolepidiaceae and to a lesser degree to the Taxodiaceae and Cupressaceae.

Based on these palaeoecological needs, we can order the macroplant fossils in a similar way as Abbink (Abbink 1998; Abbink et al. 2004) proposes for the sporomorphs (see also below), creating, thus, a PEG model (Table 1). In case of the Jurassic of Sardinia, we can distinguish four plant ecogroups, the River PEG, the humid Lowland PEG, the dry Lowland PEG and the Coastal/Tidally influenced PEG. The sphenophytes, the fern Hausmannia, the Czekanowskiales Czekanowskia and the conifer Elatocladus are living in humid environments with superficial water like along the margins of a river and/or lakes. Cheirolepidiaceans species of the conifer genus Brachyphyllum are adapted to the stressed coast environments, including mangrovial environments. The ferns Cladophlebis, Coniopteris and Todites lived in the humid Lowland PEG with a high-water table, whereas the fern Phlebopteris, the cycadophytes Nilssonia (and its seeds Cycadeospermum), Ptilophyllum (with its reproductive organs Weltrichia and Williamsonia), the putative cycadophyte Taeniopteris, the conifer Geinitzia, and the seed ferns Ctenozamites and Sagenopteris occupied the drier areas (without flooding) of the lowland. The dominant ecogroup in the Jurassic flora of Sardinia is the Lowland PEG (Table 3), where the drier Lowland PEG is more abundant (58\% in lithology 1,53\% in lithology 2) than the humid Lowland PEG (22 and 29\%, respectively). Coastal PEG and River PEG are rare in the flora $(\max 6 \%)$.

\section{Palynology}

The composition of the palyno-assemblages

Spores and pollen grains are dispersed both in continental and marine sediments providing a wide picture of the local, regional
Fig. 8 Selected spores and pollen grains from the new studied specimens (samples 3726 and 3729) of the Middle Jurassic of Sardinia (scale bar $=10 \mu \mathrm{m})$. a Cyathidites australis Couper, 1953. b Matonisporites phlebopteroides Couper, 1958. c Klukisporites scaberis (Cookson et Dettmann) Dettmann, 1963. d Staplinisporites caminus (Balme) Pocock, 1970. e Trachisporites asper Nilsson, 1958. f Osmundacidites wellmanii Couper, 1953. g Araucariacites australis Cookson, 1947. h Callialasporites turbatus (Balme) Schulz, 1967. i Pinuspollenites minimus (Couper) Kemp, 1970. j Brachysaccus microsaccus (Couper) Madler, 1964. k Alisporites robustus Nilsson, 1958. I Podocarpites multicinus (Bolchovitina) Pocock, 1970

and supra-regional distribution of the plants. The study of fossil sporomorphs permits, thus, to infer the composition of the vegetation in the past and to reconstruct palaeoenvironmental and palaeoclimatic conditions. The palynological assemblages from the Jurassic of Sardinia have been obtained for 20 palynological sections from two different geographic areas of the island (north and central-eastern).

The samples from the northern part of Sardinia (Fiume Santo, Mt. Rosé and Mt. Vaccargiu Mt.) are characterised by diversified sporomorphs with trilete spores (e.g. Obtusisporis, Neoraistrickia, Lycopodiacites, Staplinisporites, Fig. 8d, Cyathidites, Fig. 8a, Dictyophyllidites, Baculatisporites, Calamospora) and diversified pollen assemblages (e.g. Callialasporites, Fig. 8h, Tsugaepollenites, Ginkgocycadophytus, Cycadopites, Classopollis, Cerebropollenites, Araucariacites, Fig. 8g, Callialasporites) (Ashraf et al. 1984; Del Rio 1976, 1990). The sections of central-eastern Sardinia (Perdasdefogu, Tonneri Mt., Seui, Pala Asonis, Genna Su Ludu, Jerzu, Baunei and Escalaplano) yielded abundant spores (e.g. Cyathidites, Dictyophyllidites, Todisporites, Osmundacidites) and a diversified pollen assemblage (Alisporites, Brachysaccus, Vitreisporites, Cycadopites, Cerebropollenites, Classopollis, Podocarpidites, Pinuspollenites, Fig. 8i) (Del Rio 1976; Schneider 1978; SalardCheboldaeff in Dieni et al. 1983). The section of Nuraghe Nieddu near Nurallao is composed of 45 taxa, and the most abundant are spores such as Cyathidites australis, Dictyophyllidites harrisii, Gleichenidites senonicus, Matonisporites phlebopteroides (Fig. 8b) and pollen grains (Cerebropollenites mesozoicus, Classopollis classoides,
Table 3 Relative abundance of the palynological assemblages (lithofacies 1, lithofacies 2) and the palynological assemblages $(21,22)$ considering the plant ecogroups and sporomorph ecogroups

\begin{tabular}{|c|c|c|c|c|c|c|}
\hline & \multicolumn{3}{|l|}{ Plant ecogroups } & \multicolumn{3}{|c|}{ Sporomorph ecogroups } \\
\hline & Lithology $1(\%)$ & Lithology $2(\%)$ & Mean $(\%)$ & $21(\%)$ & $22(\%)$ & Mean $(\%)$ \\
\hline Coastal & 2.02 & 1.40 & 1.71 & 21.05 & 20.00 & 20.53 \\
\hline River & 2.55 & 6.01 & 4.28 & 9.47 & 10.00 & 9.74 \\
\hline Humid lowland & 22.00 & 19.13 & 20.57 & 38.95 & 32.22 & 35.58 \\
\hline Drier lowland & 58.87 & 53.77 & 56.32 & 25.26 & 27.78 & 26.52 \\
\hline Upland & 0.00 & 0.00 & 0.00 & 2.11 & 6.67 & 4.39 \\
\hline Indet. & 14.56 & 19.69 & 17.13 & 3.16 & 3.33 & 3.25 \\
\hline
\end{tabular}



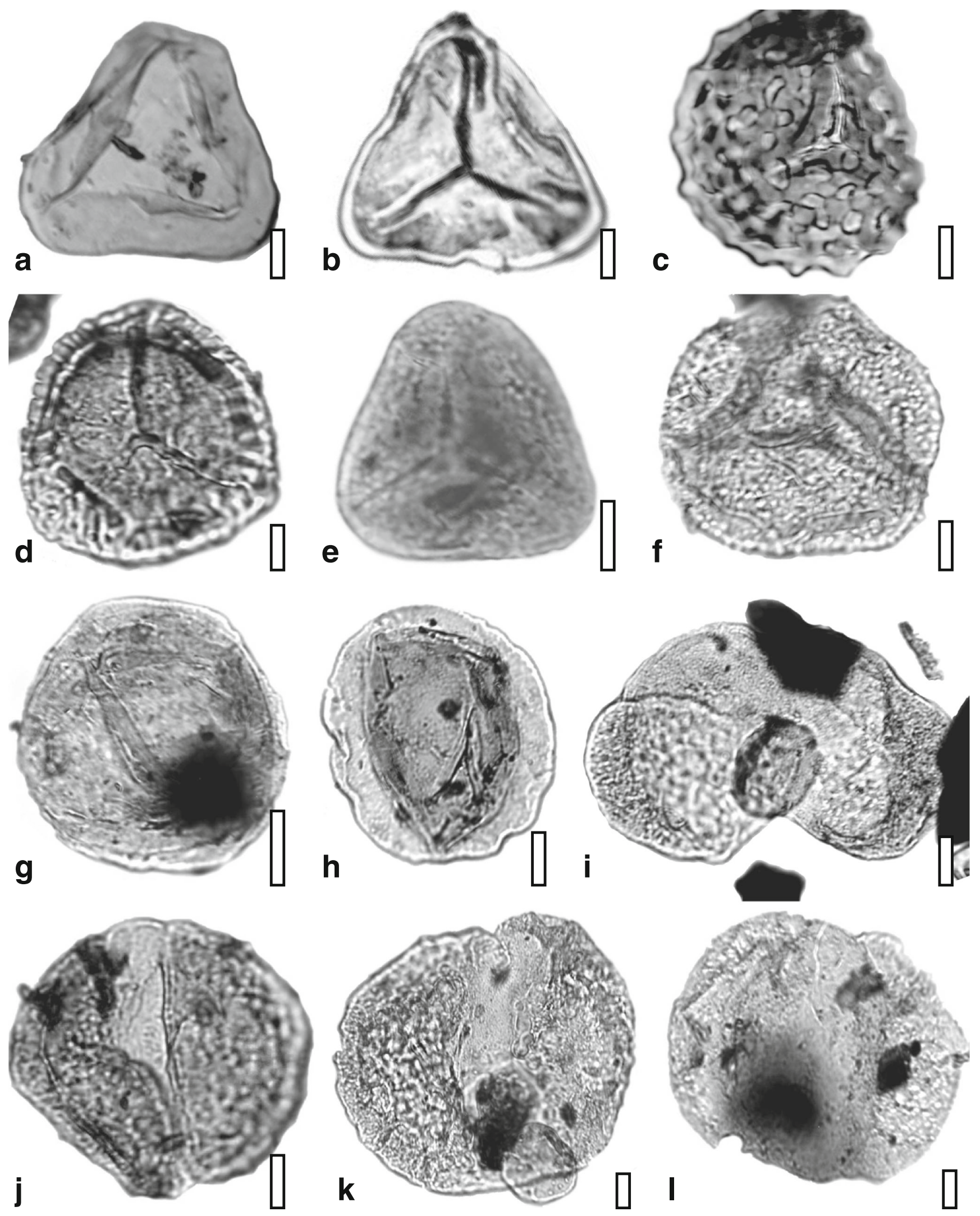

Exesipollenites laevigatus, E. scabratus, Vitreisporites pallidus, Perinopollenites elatoides, P. pseudosulcatus, Cycadopites minimum; Del Rio 1976) indicating moist and wet environments with xerophytic transported elements. 
The sporomorphs of the two samples of the collection A (Fig. 8) are well diversified with 42 spore species and 24 pollen species, attributed to 40 sporomorph genera (Table 4). The most abundant spores are the trilete forms with a smooth wall (e.g. Cyathidites, Dictyophyllidites, Todisporites, Deltoidospora, Leiotriletes, Gleichenidites). Pollens are mostly represented by non-saccate conifer pollen grains such as Araucariacites australis and Classopollis, whereas bisaccate pollen grains (e.g. Alisporites, Fig. 8k, Brachysaccus, Fig. 8j, Pinuspollenites, Podocarpidites, Fig. 81) are rare. In the light grey fine-grained siltitic facies (sample 21), the trilete spores are the most abundant (46\% of the total amount), followed by nonsaccate pollen (10\%). Perinopollenites elatoides $(7 \%)$ and Callialasporites spp. $(6 \%)$ are common, and bisaccate pollen grains, including Vitreisporites, are rare (3\%). Marine elements (acritarchs and foraminiferal linings) are present as well. In the dark grey laminated siltstone facies (samples 22), the trilete spores $(35 \%)$ are abundant. Spheripollenites (16\%), nonsaccate pollen (16\%), Callialasporites (16\%), Eucommiidites (8\%) and Perinopollenites elatoides (7.5\%) are common, whereas bisaccate pollen grains and Vitreisporites are rare (1\%). Cerebropollenites pollen are present as well $(<1 \%)$.

Botanical affinity and ecological preferences of the sporomorphs

The spores and pollen grains yielded by the Jurassic sediments of Sardinia belong to club mosses and lycophytes (e.g. Obtusisporis, Neoraistrickia, Lycopodiacites, Staplinisporites), sphenophytes (e.g. Calamospora), ferns (e.g. Cyathidites, Dictyophyllidites, Todisporites, Osmundacidites, Baculatisporites), ginkgophytes (e.g. Ginkgocycadophytus), seed fern (e.g. Alisporites, Brachysaccus, Vitreisporites), cycadophytes (e.g. Cycadopites) and conifers (e.g. bisaccate pollen grains, Classopollis, Cerebropollenites, Araucariacites, Callialasporites, Podocarpidites, Pinuspollenites) (Table 4).

Extant mosses grow under more or less humid conditions or in dry places, or they can withstand periods of draught. Jurassic mosses are considered to be of humid conditions (Abbink 1998). The lycophytes, here represented only by dispersed spores, occur today from tropical to polar regions. The genus Densoisporites is closely related to the extant family Isoetaceae, and during Jurassic and Cretaceous times probably preferred saline environments like mangrove swamps, marshes and sloughs and seashores (Retallack 1975, 1997) so that these species occur in high quantity in tidally influenced sediments (Raine et al. 1988; Abbink 1998). Uvaesporites, also well represented in our samples, has an affinity with the Selaginellales, which grow under humid conditions close to a river. A common species in the Jurassic sediments of Sardinia is Calamospora mesozoica that belongs to the Equisetales. Both extant and Jurassic groups occur in wet habitats such as river banks or lowland marshes of temperate to tropical regions.

Most extant ferns prefer humid environments both in tropical and in temperate environments although, as discussed above, they can occupy drier habitats as well. Since the ferns living in humid and warm environments are the majority, fern spores are generally used as humid indicators (Harris 1961; Van Konijnenburg-van Cittert and van der Burgh 1989). Spores of Osmundaceae (e.g. Baculatisporites, Osmundacites, Puntatisporites, Todisporites), Schizaeaceae (e.g. Duplexisporites, Ischyosporites), Dicksoniaceae (Cyathidites), Dipteridaceae (Dictyophyllidites) and Cyatheaceae (Leiotriletes) are characteristic of lowland and riparian environments. Matoniaceae (Deltoidospora, Matonisporites) preferred drier warm conditions (Abbink 1998).

Sardinian Jurassic sediments yielded also abundant seed fern pollen grains such as Vitreisporites and Alisporites. The former belongs to the Caytoniales, attributed to deltaic environments (Harris 1964) or lush lowland vegetation (Van Konijnenburg-van Cittert and Van der Burgh 1989; Kustatscher et al. 2014). Alisporites is attributed to the Corystospermales since its in situ pollen grains have been found in Pachypteris-type plants, and it has been attributed to the drier lowland. Cycadales and Bennettitales are represented by Monosulcites, Cycadopites, Chasmatosporites and Eucommiidites, but especially for the first two genera, the pollen can be distinguished only under SEM or TEM (Hill 1990). In general, cycadophyte pollen grains (s.l.) differ from the ginkgoleans ones only due to their dimension and ultrastructure (Van Konijnenburg-van Cittert 1971; Zavialova and Van Konijnenburg-van Cittert 2011). Cycadophytes were part of the drier lowland vegetation. Exesipollenites is produced by some bennettitalean plants such as Nilssoniopteris and indicates dry microclimate influences by salty wind (Watson and Sincock 1992; Zavialova et al. 2009). The non-saccate pollen (cycadophytes) and spores (bryophytes, sphenophytes and ferns) are considered as autochthonous, growing close to the depositional site.

Conifers produce often alete bisaccate pollen grains that in an environmental analysis are considered allochthonous elements, representing the upland flora growing further away from the coastal margin. Shang and Zavada (2003) suggested Cerebropollenites mesozoicus to be related with the modern Tsuga, typical of temperate regions and restricted to moist and poorly drained soils with moderate temperature. Jurassic deposits are generally rich in Classopollis pollen, which reflect an abundance of Cheirolepidiaceans (Francis 1984; Watson 1988). Cheirolepidaceans were xerophytic or drought resistant plants that general preferred upland arid habitats but also occasionally occurred in coastal areas (e.g. Van Konijnenburgvan Cittert and van der Burgh 1996; Abbink 1998), and were found mostly in argillaceous and arenaceous sediments. Classopollis has been found in situ in Brachyphyllum type 
Table 4 Relative abundance of the palynological assemblages (samples 21 and 22), the attributions to the main plant groups and to the sporomorph ecogroups

\begin{tabular}{|c|c|c|c|c|}
\hline Lithofacies 2 & $21(\%)$ & $22(\%)$ & Plant group & Spore ecogroup \\
\hline Alisporites Daugherty, 1941 & 3.16 & 3.33 & $\begin{array}{l}\text { Seed ferns, Corystospermales, in situ in Pteruchus } \\
\quad \text { (Townrow 1962) }\end{array}$ & Drier Lowland SEG \\
\hline Araucariacites Cookson ex Couper, 1953 & 4.21 & 4.44 & $\begin{array}{l}\text { Conifers, Araucariaceae (Couper 1958; } \\
\text { Van Konijnenburg-van Cittert 1971) }\end{array}$ & Coastal SEG \\
\hline $\begin{array}{l}\text { Baculatisporites Pflug et P.Thomson in } \\
\text { Thomson et Pflug, } 1953\end{array}$ & 1.05 & 1.11 & Ferns, Osmundaceae (Bonis and Kürschner 2012) & Lowland SEG \\
\hline Brachysaccus Madler, 1964 & 1.05 & 1.11 & Seed ferns & Drier Lowland SEG \\
\hline Calamospora Schopf et al., 1944 & 1.05 & 1.11 & Sphenophytes, Equisetales (Couper 1958) & River SEG \\
\hline Callialasporites Dev, 1961 & 9.47 & 10.00 & $\begin{array}{l}\text { Conifers, Araucariaceae (Van Konijnenburg-Van } \\
\text { Cittert 1971; Srivastava 1977) }\end{array}$ & Coastal SEG \\
\hline Camarozonosporites Potonié, 1956 & 1.05 & 1.11 & Bryophytes (Bonis and Kürschner 2012) & Lowland SEG \\
\hline Cerebropollenites Nilsson, 1958 & 5.26 & 3.33 & Conifers, in situ in Tsuga (Couper, 1958) & Coastal SEG \\
\hline Cibotiumspora Chang, 1965 & 1.05 & 1.11 & Ferns, Dicksoniaceae, Cyatheaceae (Filatoff 1975) & Lowland SEG \\
\hline $\begin{array}{l}\text { Concavisporites Delcourt } \\
\text { et Sprumont, } 1955\end{array}$ & 1.05 & 1.11 & $\begin{array}{l}\text { Ferns, Matoniaceae (Van Konijnenburg-Van } \\
\text { Cittert 1993) }\end{array}$ & Lowland SEG \\
\hline Cyathidites Couper, 1953 & 9.47 & 8.89 & Ferns, Dicksoniaceaen (Couper 1958) & Lowland SEG \\
\hline Deltoidospora Miner, 1935 & 3.16 & 3.33 & $\begin{array}{l}\text { Ferns, Dicksoniaceae, Cyatheaceae, Dipteridaceae, } \\
\text { Matoniaceae (Van Konijnenburg-Van Cittert 1989, } \\
\text { 1993; Balme 1995) }\end{array}$ & Drier Lowland SEG \\
\hline Densoisporites Dettmann, 1963 & 2.11 & 2.22 & $\begin{array}{l}\text { Lycophytes, Selaginellaceae (Dettmann 1963; } \\
\text { Schulz 1967) }\end{array}$ & Coastal SEG \\
\hline Dictyophyllidites Couper, 1958 & 9.47 & 7.78 & $\begin{array}{l}\text { Ferns, Dipteridaceae, Matoniaceae (Couper 1958; } \\
\text { Dettmann 1963), in situ in Phebopteris } \\
\text { polypoidioides (Scanu et al. 2015) }\end{array}$ & Drier Lowland SEG \\
\hline Duplexisporites Deak, 1962 & 1.05 & 1.11 & Ferns, Schizaceae (Tralau 1968) & Lowland SEG \\
\hline Eucommidiites Erdtman, 1948 & 0.00 & 3.33 & Cycadophytes (Abbink 1998) & Drier Lowland SEG \\
\hline Exesipollenites Balme, 1957 & 1.05 & 1.11 & Cycadophytes, Bennettitales (Harris 1969,1974 ) & Drier Lowland SEG \\
\hline Gleichenidites Ross, 1949 & 6.32 & 6.67 & Ferns, Gleicheniaceae (Potonié 1967) & Drier Lowland SEG \\
\hline Ischyosporites Balme, 1957 & 2.11 & 2.22 & $\begin{array}{l}\text { Ferns, Klukiaceae, Schizaceae (Couper 1958; } \\
\quad \text { Van Konijnenburg-van Cittert 1981) }\end{array}$ & Lowland SEG \\
\hline Leiotriletes Potonie et Kremp, 1954 & 3.16 & 2.22 & Ferns, Cyatheaceae, Gleicheniaceae (Schulz 1967) & Lowland SEG \\
\hline Leptolepidites Couper, 1953 & 1.05 & 1.11 & Ferns (Schulz 1967); tree ferns (Waksmundzka 2014) & River SEG \\
\hline Lycopodiacites Maljavkina, 1964 & 2.11 & 2.22 & Lycophytes, Lycopodiales, in situ in Lycopodium (Schulz 1967) & River SEG \\
\hline Mamunia Pocock, 1970 & 2.11 & 2.22 & Indet. & Indet. \\
\hline Marattisporites Couper, 1958 & 1.05 & 1.11 & Ferns, Marattiales & Lowland SEG \\
\hline Matonisporites Couper, 1958 & 1.05 & 1.11 & Ferns, Matoniaceae & Lowland SEG \\
\hline Neoraistrickia Potonié, 1956 & 1.05 & 1.11 & Lycophytes, Lycopodiales (Abbink et al. 2004) & River SEG \\
\hline Obtusisporites (Krutzsch) Pocock, 1970 & 1.05 & 1.11 & Bryophytes & Indet. \\
\hline $\begin{array}{l}\text { Osmundacidites Danzé-Corsin } \\
\text { et Laveine, } 1963\end{array}$ & 1.05 & 1.11 & Ferns, Osmundaceae (Dettmann 1963) & Lowland SEG \\
\hline Perinopollenites Couper, 1958 & 3.16 & 3.33 & $\begin{array}{l}\text { Conifers, in situ in Elatides williamsonii, Taxodiaceae } \\
\text { (Couper 1958; Van Konijnenburg-van Cittert 1971) }\end{array}$ & Lowland SEG \\
\hline Pinuspollenites Raatz ex Potonié, 1958 & 1.05 & 1.11 & Conifers, Pinaceae (Bonis and Kürschner 2012) & Upland SEG \\
\hline Podocarpidites Cookson ex Couper, 1953 & 1.05 & 1.11 & Conifers, Podocarpaceae (Filatoff, 1975) & Upland SEG \\
\hline Retitriletes Pierce, 1691 & 2.11 & 2.22 & Ferns (Bonis and Kürschner 2012) & Lowland SEG \\
\hline Sestrosporites Dettmann, 1963 & 1.05 & 1.11 & Lycophytes, Lycopodiales (Gedl and Ziaja 2012) & River SEG \\
\hline Spheripollenites Couper, 1958 & 0.00 & 4.44 & Conifers (Gedl and Ziaja 2012) & Upland SEG \\
\hline Staplinisporites Pocock, 1962 & 2.11 & 2.22 & $\begin{array}{l}\text { Lycophytes, Lycopodiaceae, Selaginellaceae } \\
\text { (Filatoff 1975) }\end{array}$ & River SEG \\
\hline Todisporites Couper, 1958 & 7.37 & 1.11 & $\begin{array}{l}\text { Ferns, Osmundaceae, in situ in Todites goeppertianus, } \\
\text { T. williamsonii (Couper 1958; Tralau 1968; } \\
\text { Van Konijnenburg-van Cittert 1978) }\end{array}$ & Lowland SEG \\
\hline Trachysporites Nilsson, 1958 & 2.11 & 2.22 & Ferns (Bonis and Kürschner 2012) & Lowland SEG \\
\hline Uvaesporites Döring, 1965 & 1.05 & 1.11 & Lycophytes, Selaginellales (Raine et al. 2011) & River SEG \\
\hline Varirugosisporites Döring, 1965 & 1.05 & 1.11 & Ferns, Schizaceae (Gedl and Ziaja 2012) & Lowland SEG \\
\hline $\begin{array}{l}\text { Vitreisporites Danzé-Corsin } \\
\text { et Laveine in Briche et al., } 1963\end{array}$ & 1.05 & 1.11 & $\begin{array}{l}\text { Seed ferns, Caytoniales, in situ in Caytonianthus } \\
\quad \text { (Chaloner and Muir 1968) }\end{array}$ & Drier Lowland SEG \\
\hline
\end{tabular}


of conifers belonging to the Cheirolepidiaceae and sometimes could be considered as mangrove plant (Barale et al. 1991). Araucariacites and Callialasporites pollen grains belong to the Araucariaceae (Schulz 1967; Tralau 1967; Boulter and Windle 1993). A high frequency of these pollen grains during Jurassic times is correlated with a warm climate (Reyre 1980; Mohr 1989).

Considering the major plant groups (Table 2), it becomes evident that the ferns are the dominant element (55 and 47\%, respectively, in the two lithological samples), followed by the coniferophytes (24 and 28\%). Lycophytes reach still $10 \%$, seed ferns $5 \%$, whereas the spores of the bryophytes, sphenophytes and pollen grains of cycadophytes and Czekanowskiales are rare (Table 2).

Palaeoenvironmental considerations based on the SEG method

The SEG method was applied to the palynological samples coming from the Lovisato collection (Table 3). The bryophyte spores belong either to the river SEG (Staplinisporites) or wetland areas of the lowland SEG (Camarozonosporites), due to the fact that mosses usually live in humid areas. Lycophyte spores may be attributed to the river (e.g. Lycopodiacidites, Neoraistrickia, Sestrosporites) or coastal SEG (e.g. Densoisporites); sphenophytes (Calamospora) are indicative of the river SEG.

Most fern spores live in humid areas and are, thus, included in the humid lowland SEG (e.g. Baculatisporites, Concavisporites, Cibotiumspora, Cyathidites, Duplexisporites, Gleichenidites, Ischyosporites), drier lowland SEG (e.g. Deltoidospora, Dictyophyllidites, Gleichenidites) and river SEG (e.g. Leptolepidites). Seed fern pollen grains are included in the drier lowland SEG (Alisporites, Brachysaccus, Vitreisporites). The cycadophyte pollen Cycadopites and Eucommiidites and the bennettitalean pollen Exesipollenites are attributed to the dry lowland SEG. Saccate conifer pollen grains are represented here by Pinuspollenites and Podocarpidites, which belong to the upland SEG. Araucariacites and Callialasporites (Araucariaceae), Spheripollenites and Cerebropollenites (Taxodiaceae) and Classopollis (Cheirolepidaceae) are assigned to the coastal SEG (Francis 1983; Vakhrameev 1981; Watson 1988), the latter growing in swamp paralic environments, which are ecologically similar to extant mangroves (Courtinat 2000). Perinopollenites is produced by Elatides, an extinct Taxodiaceous conifer that prefers moist environments and belongs to the wet lowland SEG.

Considering the various SEGs, the two lithofacies of the Lovisato collection are almost identical, supporting the idea that they come from the same palaeoenvironment (same lithofacies) and/or palaeoclimatic conditions. The dominant group is the lowland SEG (60-64\%), in which the humid lowland elements are more abundant (32-39\%) than the dry lowland SEG (25-28\%). The coastal SEG is second in abundance $(20-21 \%)$, whereas river and upland SEG are rarer.

\section{Palaeoenvironmental reconstruction of the Genna Selole Formation in Sardinia}

During the Jurassic, the Sardinian area belonged to the Corsica-Sardinia block, located in the eastern part of the developing Iberian microplate (Stampfli 2000 and ref. therein). The Corsica-Sardinia block was located at $\sim 35^{\circ} \mathrm{N}$ near the western border of the Tethys, very close to the margin of the European plate (Fig. 9). During the Early Jurassic, the area was covered by a shallow sea with carbonate sedimentation (Cherchi 1986; Costamagna 2016). During the early Middle Jurassic, the opening of the Alpine extension of the Tethys triggered the ephemeral rise of the Eastern Sardinia block, and the gradual shallowing of the western part of the island (Costamagna 2016). The rise of the eastern part of Sardinia triggered the erosion of part of the older successions down to the Paleozoic Variscan basement, the Middle Triassic-Early Jurassic carbonate deposits and the remains of the Carboniferous to Permian rocks left behind by the former erosive events. Conversely, western Sardinia, representing only a distal slope of the eastern Sardinia area, became a shallow marine environment with the sedimentation of paralic-coastal marly deposits with characeae, ostracods, pollen grains and Fe-rich encrusted surfaces (Cherchi and Schroeder 1986) resembling condensation surfaces, or, perhaps, suggesting emersion times. After the late Aalenian-early Bathonian in the eastern part, and the late Aalenian-early Bajocian in the western part, the island was submerged in a shallow sea where carbonate deposition took place. The alluvial fans were covered by palustrine-coastal plains, the plains by transitional to marine lagoons and bars. At the end, sea covered them all and the carbonate Jurassic shelf sedimentation recovered (Costamagna 2015, 2016).

However, the emersion of the Eastern Sardinia block during the early Middle Jurassic was not uniform, but an extension caused the fragmentation of the main block in minor subblocks separated by internal graben systems with diverse subsidence rates (Fig. 10). This gave origin to an archipelago (Costamagna 2016) formed by small emerged areas surrounded by a thin belt formed by transitional sediments passing from continental to marine (Fig. 11). The highs were subjected to pedogenization and/or erosion (Costamagna and Vacca in press), while the lows were filled by debris. The whole block surface was, thus, an articulated landscape on which the Middle Jurassic siliciclastic to carbonate successions of the Genna Selole Formation were deposited unconformably. The erosion of the emerged sub-blocks provided the coarse- to fine-grained debris that maturated during the transport and is dominated by quartz elements. Initially, the sediments derived mainly from the dismantling of the pre-Middle Jurassic rocks. They were coarse, angular and contained a certain percentage of schists, metavolcanics and carbonates. Later, it became finer and smoother and formed only by quartz 


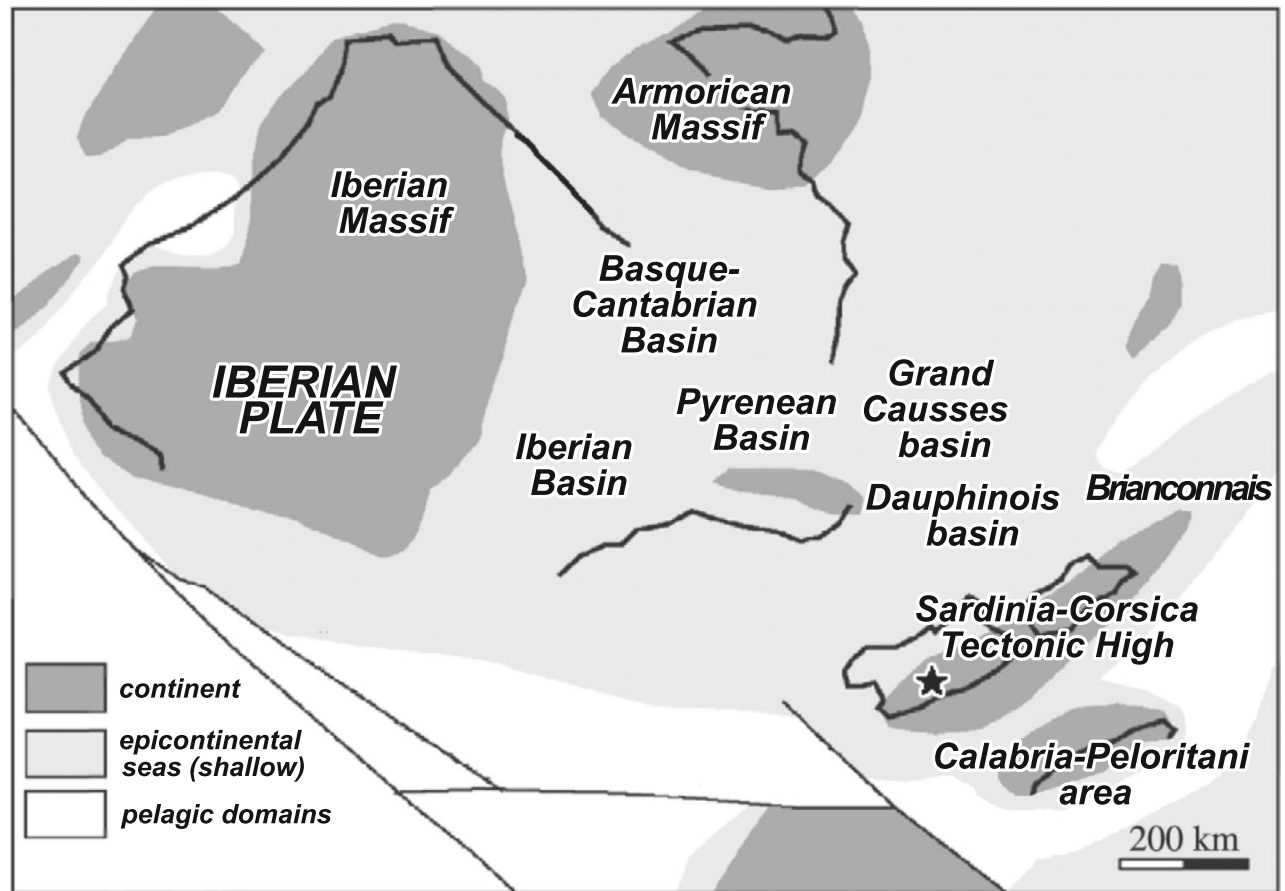

Fig. 9 Palaeogeographic position of the Sardinian block during the Middle Jurassic (after Costamagna 2015)

(Costamagna 2015, 2016). The thickness and composition of the Genna Selole Formation (0-78 m; Fig. 3) depends, thus, on its topographic position (Dieni et al. 1983; Costamagna and Barca 2004; Costamagna 2013, 2015, 2016).

The depositional environments surrounding the tectonic blocks and sub-blocks were influenced by the sinking of the entire block, the filling of the depressions by sediment and progressive levelling of the landscape due to the reduction of the altitude gap. During the rise of the high and the developing regression, when the landscape was more articulated, rivers dug their way in bedrock along faults cutting the tectonic highs and deposited prograding alluvial fans and braided fluvial bars ending possibly in braided deltas, the Laconi-Gadoni (LG) lithofacies of the Genna Selole Formation (Fig. 12; Costamagna 2015). The alluvial fans interfingered in the inter-valley areas with narrow palustrine-coastal plains that were occasionally tidally influenced. This are the pelitic deposits of the Nurri-Escalaplano (NE) lithofacies of the Genna Selole Formation. Towards the sea, in the lagoons, those deposits gave place to mixed carbonate-sandy-marly tidal deposits representing transitional sediments to the carbonate deposits of the shallow open sea. This is the Ussassai-Perdasdefogu (UP) lithofacies of the Genna Selole Formation (Fig. 3; Costamagna 2015).

The sediments forming the sections of the northern part of Sardinia (Fiume Santo, Mt. Rosé and Mt. Vaccargiu) were deposited in transitional facies or lagoonal phases of freshwater to brackish environments (Ashraf et al. 1984; Del Rio 1976,1990 ) suggesting an ephemeral shallowing area in a carbonate shelf environment, with a close, emerged area to the east. The sections of central-eastern Sardinia (Perdasdefogu, Tonneri Mt., Seui, Pala Asonis, Genna $\mathrm{Su}$ Ludu, near Jerzu, Baunei) reflect a riparian, floodplain and coastal vegetation (Del Rio 1976, 1984), brackish environment with lagoonal black shales (Del Rio 1976) and continental environment (Schneider 1978; Salard-Cheboldaeff in Dieni et al. 1983; Costamagna and Barca 2004; Costamagna 2015). The successions of Nuraghe Nieddu Quarry near Nurallao and Escalaplano were deposited in continental to marine environments (Del Rio 1976).

The various Middle Jurassic successions of Sardinia were clustered based on their palynological composition (Fig. 13). This cluster analysis grouped the samples in four groups, reflecting four sub-environments that can be matched with four different lithofacies of the Genna Selole Formation. The first cluster (blue colour, samples S1, S9, S21 and S22) is characterised by a high diversity and abundance of fern spores (e.g. Cyathidites, Dictyophyllidites, Ischyosporites, Leiotriletes) and cycadophyte (Cycadopites) and conifer pollen (e.g. Araucariacidites, Callialasporites). This cluster includes also the samples collected from the Lovisato collection, yielding the plant macrofossils (S21, S22). It reflects a lush and diverse vegetation, typical of the wet to slightly dry environment of the lowland SEG/PEG as discussed above. This cluster could reflect a backswamp or freshwater pool flanking a shifting upper braidplain and may correspond to the lower LG lithofacies of the Genna Selole Formation. The second cluster (green, S2, S4, S10, S11, S12, S13) is characterised by a lower diversity. Common elements of all these samples are the lycophyte spore Densoisporites, in combination with 

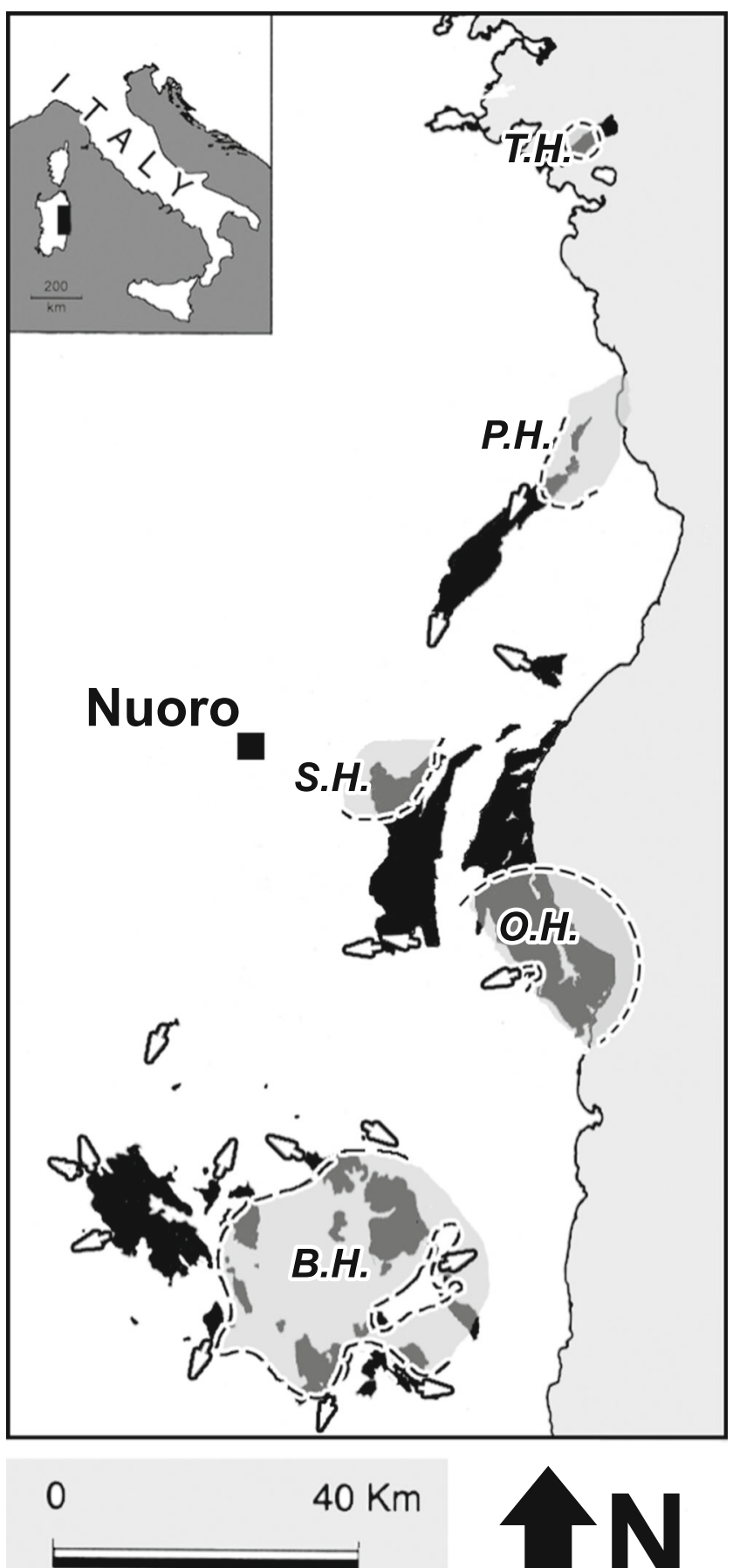

$40 \mathrm{Km}$

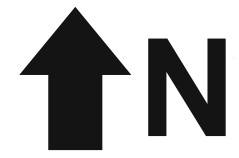

Fig. 10 Main tectonic emerged sub-highs during Aalenian to Bathonian times (after Costamagna 2015)

the seed fern pollen Vitreisporites, the cycadophyte pollen Eucommiidites and the conifer pollen Cerebropollenites and Classopollis. Most of these elements are typical for or are also present in the coastal SEG/PEG, where the plants need to be stress-resistant against physiological dryness. These samples may be deposited in a fluvial environment of low energy, located laterally to the lower reach for a sluggy river, close to the coastline. This environment could correspond to the NE lithofacies of the Genna Selole Formation.

The third cluster (yellow: S14, S15, S16, S17, S18, S19, S20) is characterised by a medium diversity. The cluster is mainly featured by wind-blown pollen grains and rare fern spores (e.g. Cyathidites, Matonisporites, Gleichenidites). The pollen grains belong to the seed ferns (Alisporites), cycadophytes (Cycadopites) and conifers (Cerebropollenites, Classopollis, Exesipollenites, Perinopollenites). This assemblage is characterised by plants that are adapted to drier environments and are mostly wind-pollinated. This cluster corresponds either to an environment that is subjected to short periods of aridity or, more likely, to a greater distance between the producing and the depositional environment, i.e. a fluvial environment that was located farther from the main river course or upland. Nonetheless, it has to be noticed that short drier periods during the sedimentation of the Genna Selole Formation have been suggested by Costamagna and Vacca (in press) based on the presence of Fe-rich crusts coating the bedding surfaces of the conglomerates of the LG lithofacies, that in this case could be a good match. This would confirm a correlation with the more arid Lowland SEG/PEG for this cluster as a source. The last cluster (red: S3, S5, S6, S7, S8) is agglomerated with a generally very low diversity. The only highly abundant and common taxa are the conifer pollen Araucariacites, Exesipollenites and Classopollis, together with the fern spores Gleichenidites and Cyathidites. Thus, the main elements are wind-blown pollen suggesting either a drier environment, still correlatable with short periods of aridity of the LG Genna Selole Formation facies (arid lowland SEG/PEG), or with a greater distance from the coastal line, thus corresponding to the upland/ hinterland SEG/PEG. Considering the palaeogeographic distribution of the studied samples, the former theory seems the more plausible one.

\section{Concluding remarks}

During the Middle Jurassic, Sardinia was covered by a diverse landscape with a variety of habitats occupied by terrestrial plants and animals. Unfortunately, fossils of vertebrates and invertebrates colonising the emerged islands are missing so far with the exception of some freshwater branchiopod crustaceans found in the fine-grained lithology (Krasser 1920; Kustatscher et al. 2016; Fig. 6f). The integrated palaeobotanical, palynological and lithofacies analyses permitted to reconstruct this complex landscape and to identify four different environments. These analyses confirmed the continental subdivision of Costamagna (2015) but allowed also to distinguish further the lithofacies previously proposed by Costamagna and Barca (2004) in the Genna Selole Formation, separating diverse sub-environments featured by different extent of humidity in the Laconi-Gadoni lithofacies. 


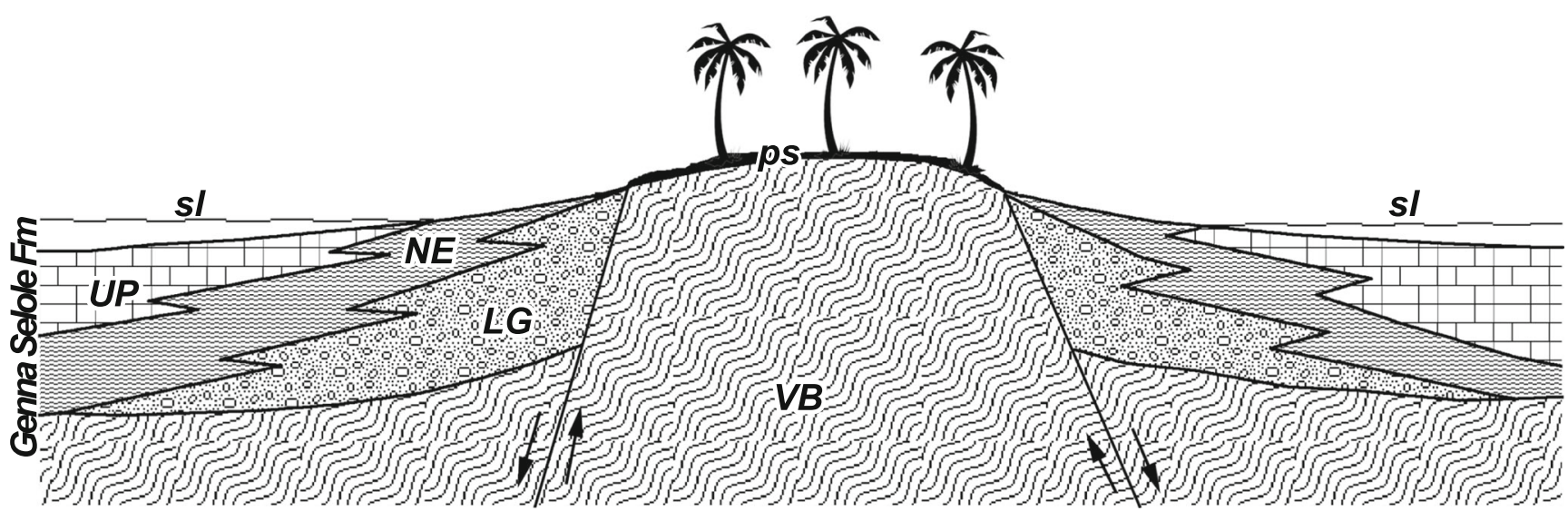

Fig. 11 Schematic palaeoenvironmental reconstruction of the Genna Selole Formation lithofacies around an emerged tectonic sub-high

The qualitative and quantitative studies on macrofossils and sporomorphs performed on the Lovisato collection permit also to compare the results of both proxies and to integrate these data with those from previous works (Tables 2 and 3; Fig. 10). This comparison evidences marked differences between the results of both datasets as observed also in previous works (e.g. Kustatscher et al. 2010, 2012, 2014), since the macrofossils reflect more local palaeoenvironments, whereas palynomorphs reflect more regional climatic conditions combined with local elements.
The Lovisato plant macrofossil collection is a rich plant assemblage composed of 19 different genera attributable to sphenophytes, ferns, seed ferns, cycadophytes, Czekanowskiales and conifers (Scanu et al. 2015, 2016; Kustatscher et al. 2016). The cycadophytes are most important group (50\%; Table 2), if the slight difference in composition between the two lithofacies is ignored (we use here always the mean value between the samples). This dominance is mostly caused to the high abundance of leaf fragments of the

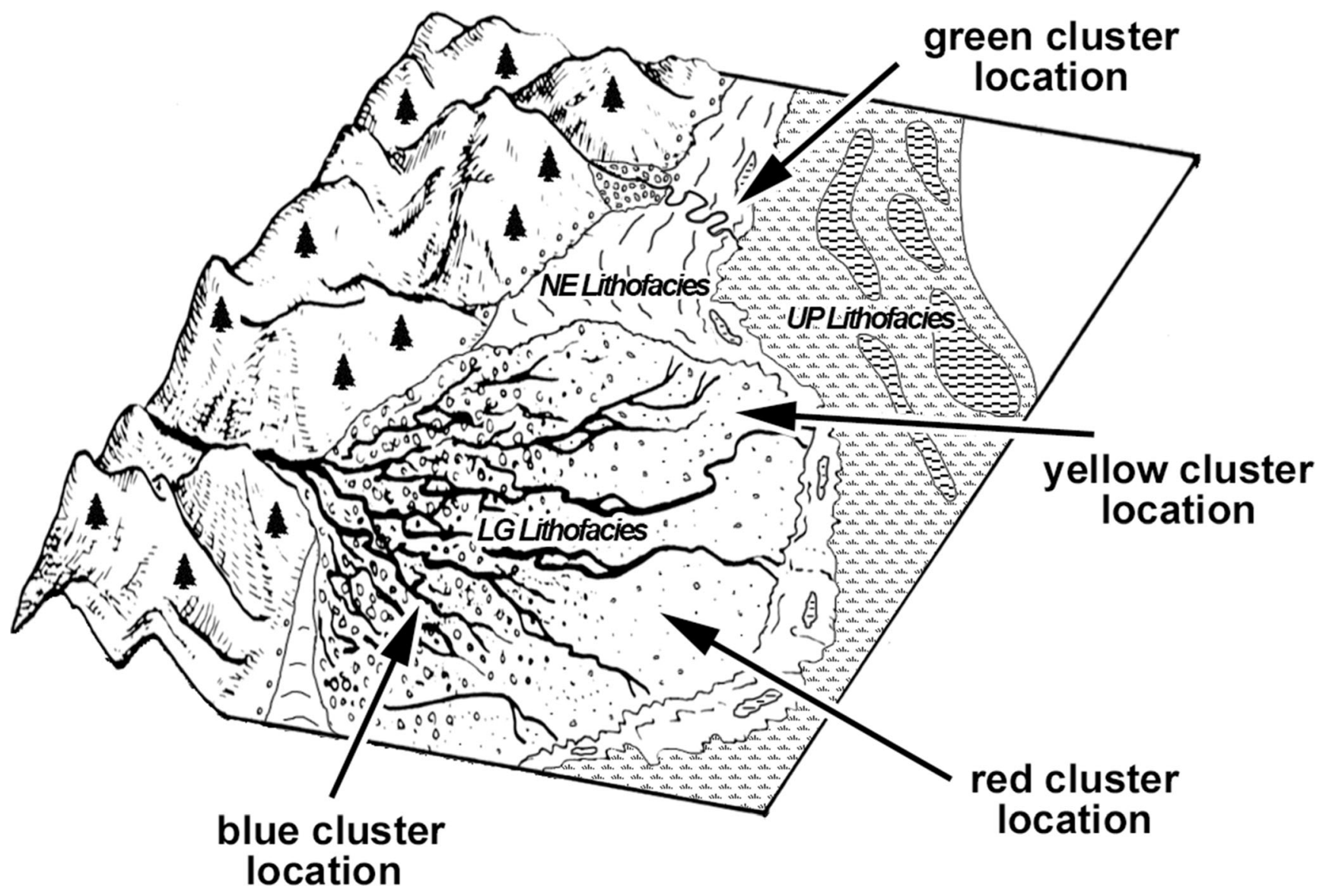

Fig. 12 Palaeoenvironments of the Genna Selole Formation lithofacies and locations of the section discussed in the cluster analyses 


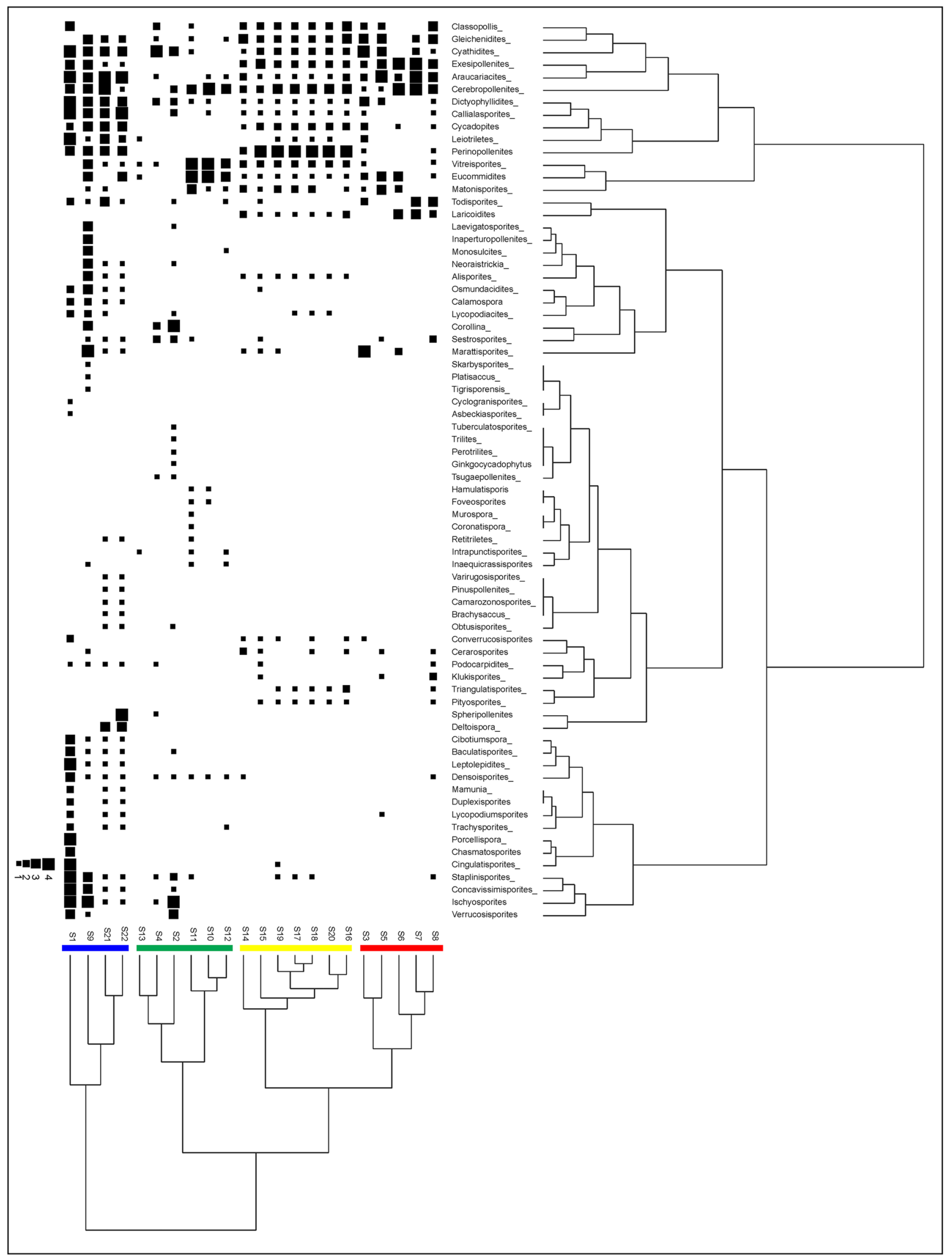


4 Fig. 13 Cluster analyses based on the palynological composition of the various Middle Jurassic sedimentary successions. Horizontally is disposed the clustering of the different sporomorph genera, vertically the clustering of the different samples/localities based on both literature and new data. The squares indicate the different abundances: (1) present $(<3 \%),(2)$ common (4-7\%), (3) frequent $(8-11 \%)$, and (4) abundant $(>12 \%)$

bennettitalean genus Ptilophyllum. However, the dominance of the cycadophytes in the macroremains is not at all reflected in the palynological assemblage, where the cycadophytes reach only less than $5 \%$ (Table 2 ). The dominant elements of the palynological samples are the ferns $(50 \%)$, which are second in order of abundance in the Lovisato collection (26\%). The conifers, second in order of abundance among the sporomorphs, are rare $(3 \%)$ in the plant macroassemblages. There are also elements that are represented only in one of the two proxies, such as the Czekanowskiales that have been recorded only among the macroremains, and the lycophytes and bryophytes that appear only in the palynological analyses. In case of the bryophytes and lycophytes, this could be related to the brittle and delicate nature of their vegetative organs and small remains of the plants (e.g. Van Konijnenburg-van Cittert et al. 2014, 2016). Regarding the missing Czekanowskiales pollen, this could be related to the fact that numerous pollen types have been identified in association with the seed micropyles but none occurs with sufficient frequency to be regarded as that of Leptostrobus Heer, 1876 (its reproductive structure). Indeed, some grains appear to be inaperturate, whereas others are distinctly bisaccate (Harris and Miller in Harris et al. 1974). The lack of data could, thus, also be due to the missing assignment of pollen to this group. Attached to the cuticles of Czekanowskia sp. cf. C. furcula of the Lovisato collection, Circumpolles-type of pollen grains have been identified as well.

If the composition is observed not based on the botanical affinity of the remains but based on the spatial distribution of the plants that produced the studied micro- and macroremains, a similar picture of distinct shift between the major groups (SEGs and PEGs) can be observed. In both proxies, the lowland elements constitute the dominant group (77\% in PEG, $62 \%$ in SEG). However, within the lowland group, the proportions are shifted. In the Lovisato collection, the drier elements dominate (56 vs $21 \%$ ), whereas among the sporomorphs, the humid elements are more abundant $(35 \%)$. This could be partly related to the high abundance of Ptilophyllum mentioned above among the macroremains. Nonetheless, this result is surprising since the humid lowland SEG is composed mainly of fern spores, which are water transported and generally considered not to travel over long distances. This could suggest that the sporomorphs reflect a (para)autochtonous assemblage where the elements were not transported over a long distance. This would also be supported by the high abundance of coastal elements $(20.5 \%)$ among the sporomorphs, contrary to a low abundance of coastal elements among the macroremains. River elements are common but not very abundant in both datasets $(4 \%$ in PEG vs $10 \%$ in SEG). Unsurprisingly, on the other hand, is the lack of distinct upland/hinterland elements among the macroremains, but the reduced number of palynomorph upland SEG elements is more a surprise. It could, however, be explained by the reduced upland area present in this rather flat and small emerged land.

This study underlines how important the integrations of palaeobotanical, palynological and lithofacies/sedimentological analyses are for the reconstruction of the palaeoenvironment. Palaeobotanical analyses themselves would have supported a generally warm and arid climate due to the high abundance of xeromorphic characters (e.g. in Ptilophyllum, Ctenozamites) and the abundance of bennettitalean leaves, in combination with a longer transport of plant macroremains. The palynological analyses would have supported a warm to tropical humid climate due to the dominance of the ferns, whereas the conifers would have been interpreted as the background noice of the upland/hinterland flora. The combination of the three analyses leads to an articulated landscape with tectonic blocks and sub-blocks which were eroded by rivers giving origin to prograding alluvial fans and braided fluvial bars ending in braided deltas. These alluvial fans interfingered with narrow palustrine-coastal plains that were occasionally tidally influenced, and, more distally, lagoons. Several different habitats originated in this complex landscape: a reduced upland/hinterland area, an extensive lowland area and a small coastal environment that might be influenced by sea-level rises. The coastal habitat is colonised by lycophytes (Densoisporites spores) and araucariacean (Araucariacites, Callialasporites pollen) and cheirolepidiacean conifers (Brachyphyllum). The drier parts of the lowland are characterised by seed ferns (Ctenozamites, Sagenopteris), cycadophytes (Nilssonia, Ptilophyllum), conifers (Geinitzia) and dipteridacean and gleicheniacean ferns (Phlebopteris, Gleichenidites spores), among others. The more humid parts of the lowland environment were covered by bryophytes (Camarozonosporites spores), osmundacean, matoniacean, marattialean and schizaeacean ferns (Cladophlebis, Coniopteris, Todites). The environment surrounding the river and water bodies is colonised by humid elements such as lycopodialean lycophytes (e.g. Neoraistrickia spores), sphenophytes (Calamospora spores), ferns (Hausmannia), Czekanowskiales (Czekanowskia) and some conifers that are adapted to humid environments such as Elatocladus. The upland/hinterland is represented in the palynological assemblages by pinacean and podocarpacean conifers (Pinuspollenites, Podocarpidites).

The abundance of bennettitalean leaves is, thus, mainly a preservation artefact and does not reflect climatic 
conditions. A diverse plant association (19 macroflora genera and 40 sporomorph genera) thrived under the generally warm and humid conditions, although drier periods occurred as well (Costamagna and Vacca, in press), based on the presence of Fe-rich crusts coating some the bedding surfaces. Like the floras of Yorkshire and Hungary (Van Konijnenburg-van Cittert and Morgans 1999, Barbacka 2011, Barbacka et al. 2010, 2014), also the Middle Jurassic plants of Sardinia were adapted to a series of different environments that can be distinguished in the complex landscape. Further studies in Western (Nurra) and Eastern (Tacchi, Ogliastra) Sardinia could permit to correlate coeval periods of continentality development during Bajocian-Bathonian times.

Acknowledgements Carla Buosi from Cagliari University is kindly thanked for her valuable suggestions in statistical analysis. Two anonymous reviewers are thanked for their helpful comments on the paper. The Krasser material of Prague was studied by EK during a visit to the National Museum in Prague under the project "The diversity of the Jurassic floras of Europe" (CZ-TAF-4535), which received funding through SYNTHESYS, which was made available by the European Community-Research Infrastructure Action under the FP7 "Structuring the European Research Area" Programme. GGS gratefully acknowledges the Sardinia Regional Government for its PhD scholarship (P.O.R. Sardegna F.S.E. Operational Programme of the Autonomous Region of Sardinia, European Social Fund 2007 - 2013 - Axis IV Human Resources, Objective 1.3, Line of Activity 1.3.1). This paper is also part of the UNESCO-IUGS IGCP Project 632 "Continental Crises of the Jurassic: Major Extinction Events and Environmental Changes within Lacustrine Ecosystems". The authors thank the Department of Innovation, Research and University of the Autonomous Province of Bozen/Bolzano for covering the Open Access publication costs.

\section{Compliance with ethical standards}

Conflict of interest: The authors declare that they have no conflict of interest.

Open Access This article is distributed under the terms of the Creative Commons Attribution 4.0 International License (http:// creativecommons.org/licenses/by/4.0/), which permits unrestricted use, distribution, and reproduction in any medium, provided you give appropriate credit to the original author(s) and the source, provide a link to the Creative Commons license, and indicate if changes were made.

\section{References}

Abbink, O.A. (1998) Palynological investigations in the Jurassic of the North Sea region. Utrecht: $\mathrm{PhD}$ thesis, University of Utrecht.

Abbink, O., Van Konijnenburg-van Cittert, J. H. A., \& Visscher, H. (2004). A sporomorph ecogroup model of the Northwest European Jurassic-Lower Cretaceous: concepts and framework. Geologie en Mijnbouw, 83, 17-38.

Alvin, K. L. (1982). Cheirolepidiaceae: biology, structure and paleoecology. Review of Palaeobotany and Palynology, 37, 71-98.

Ashraf, A. R., Cherchi, A., \& Schroeder, R. (1984). Pollen und Sporen aus dem mittleren Dogger von NW Sardinien (Italien). Palaeontographica B, 192, 1-15.
Balme, B. E. (1995). Fossil in situ spores and pollen grains: an annotated catalogue. Review of Palaeobotany and Palynology, 87, 81-323.

Barale, G., Philippe, M., \& Thevenard, F. (1991). L'approche morphologique en paléobotanique: Application à l'étude du jurassique. Geobios, 24, 57-67.

Barbacka, M. (2009). Sphenophyta from the Early Jurassic of the Mecsek Mts., Hungary. Acta Palaeobotanica, 49(2), 221-231.

Barbacka, M. (2011). Biodiversity and the reconstruction of Early Jurassic flora from the Mecsek Mountains (southern Hungary). Acta Palaeobotanica, 51, 127-179.

Barbacka, M., \& Bodor, E. (2008). Systematic and palaeoenvironmental investigations of fossil ferns Cladophlebis and Todites from the Liassic of Hungary. Acta Palaeobotanica, 48(2), 133-149.

Barbacka, M., Pálfy, J., \& Smith, P. L. (2006). Hettangian (Early Jurassic) plant fossils from Puale Bay (Peninsular terrane, Alaska). Review of Palaeobotany and Palynology, 142, 33-46.

Barbacka, M., Ziaja, J., \& Wcisło-Luraniec, E. (2010). Taxonomy and palaeoecology of the Early Jurassic macroflora from Odrowąż, central Poland. Acta Geologica Polonica, 60(3), 373-392.

Barbacka, M., Bodor, E., Jarzynka, A., Kustatscher, E., Pacyna, G., Popa, M. E., Scanu, G. G., Thévenard, F., \& Ziaja, J. (2014). European Jurassic floras: Statistics and palaeoenvironmental proxies. Acta Palaeobotanica, 54, 173-195.

Barbacka, M., Popa, M. E., Mitka, J., Bodor, E., Püspöki, Z., \& McIntosh, R. W. (2016). A quantitative approach for identifying plant ecogroups in the Romanian Early Jurassic terrestrial vegetation. Palaeogeography, Palaeoclimatology, Palaeoecology, 446, 44-54.

Barrón, E., Gómez, J. J., Goy, A., \& Pieren, A. P. (2006). The TriassicJurassic boundary in Asturias (northern Spain): Palynological characterisation and facies. Review of Palaeobotany and Palynology, 138, 187-208.

Barth, G., Franz, M., Heunisch, C., Kustatscher, E., Thies, D., Vespermann, J., \& Wolfgramm, M. (2014). Late Triassic (NorianRhaetian) brackish to fresh water habitats at a fluvial-dominated delta plain (Seinstedt, Lower Saxony, Germany). Palaeobiodiversity and Palaeoenvironments, 94(4), 495-528.

Batten, D. J. (1974). Wealden palaeoecology from the distribution of plant fossils. Proceedings of the Geological Association, 85(4), 433-458.

Bonis, N. R., \& Kürschner, W. M. (2012). Vegetation history, diversity patterns, and climate change across the Triassic/Jurassic boundary. Paleobiology, 38(2), 240-264.

Boulter, M. C., \& Windle, T. (1993). A reconstruction of some Middle Jurassic vegetation in Northern Europe. Special Papers in Palaeontology, 49, 125-154.

Briche, P., Danzé-Corsin, P., \& Laveine, J. P. (1963). Flore infraliasique du Boulonnais (macro-et microflore). Mémoires Societé Géologique du Nord, 13, 57-143.

Brongniart, A.T. (1828)-37 Histoire des végétaux fossiles, ou Recherches botaniques et géologiques sur les végétaux renfermes dans les divers couches du globe vol. I. Paris: G. Dufour et E. D’Ocagne.

Cantrill, D. J. (1995). The occurrence of the fern Hausmannia Dunker (Dipteridaceae) in the Cretaceous of Alexander Island, Antarctica. Alcheringa, 19, 243-254.

Carmignani, L., Carosi, R., Di Pisa, A., Gattiglio, M., Musumeci, G., Oggiano, G., \& Pertusati, P. C. (1994). The Hercynian chain in Sardinia. Geodinamica Acta, 7, 31-47.

Carmignani, L., Oggiano, G., Barca, S., Conti, P., Salvadori, I., Eltrudis, A., Funedda, A., \& Pasci, S. (2001). Geologia della Sardegna. Note illustrative della Carta Geologica della Sardegna a scala 1:200.000. Memorie Descrittive della Carta Geologica d'Italia. In Servizio Geologico 60. Roma: Istituto Poligrafico e Zecca dello Stato.

Cassinis, G., \& Ronchi, A. (2002). The (Late-) Post-Variscan continental successione of Sardinia. Rendiconti della Società Paleontologica Italiana, 1, 169-176. 
Chaloner, W. G., \& Muir, M. (1968). Spores and Floras. In D. Murchison \& T. S. Westall (Eds.), Coal and coal bearing strata (pp. 127-146). Edinburgh: Oliver and Boyd.

Cherchi A. (ed.) (1986). 19th European Micropaleontological ColloquiumSardinia, Italy, October 1-10, 1985. Cagliari: Agip SpA, Guide book, 85 pp.

Cherchi, A., \& Schroeder, R. (1986) Bajocian of Monte Vaccargiu. In A. Cherchi (Ed.), 19th Micropal. Colloq., Sardinia, Italy, October $1985,146-150$

Cleal, C. J., \& Rees, P. M. (2003). The Middle Jurassic flora from Stonesfield, Oxfordshire, UK. Palaeontology, 46, 739-801.

Cookson, I. C. (1947). Plant microfossils from the lignites of Kerguelen archipelago: B.A.N.Z. Antarctic research expedition 1929-1931. Report Serie A, 2, 127-142.

Costamagna, L.G. (2013) Transgressive evolution and paleoenvironments of a mixed depositional system in a tectonicallyactive context: the early Middle Jurassic of Eastern Sardinia. JMES Special Issue, 45-48.

Costamagna, L. G. (2015). Middle Jurassic continental to marine transition in an extensional tectonics context: the Genna Selole Fm depositional system in the Tacchi area (central Sardinia, Italy). Geological Journal, 51, 722-736.

Costamagna, L. G. (2016). The Middle Jurassic Alpine Tethyan Unconformity and the Eastern Sardinia - Corsica Jurassic High: A sedimentary and regional analysis. Journal of Iberian Geology, 42(3), 311-334.

Costamagna, L. G., \& Barca, S. (2002). The "Germanic" Triassic of Sardinia (Italy): a stratigraphic, depositional and paleogeographic review. Rivista Italiana di Paleontologia Stratigrafica, 108, 67-100.

Costamagna, L. G., \& Barca, S. (2004). Stratigrafia, analisi di facies, paleogeografia ed inquadramento regionale della successione giurassica dell'area dei Tacchi (Sardegna Orientale). Bollettino della Società Geologica Italiana, 123(3), 477-495.

Costamagna, L. G., Barca, S., \& Lecca, L. (2007). The BajocianKimmeridgian Jurassic sedimentary cycle of eastern Sardinia: Stratigraphic, depositional and sequence interpretation of the new "Baunei Group". Comptes Rendus Geoscience, 390, 601-612.

Couper, R. A. (1953). Upper Mesozoic and Cainozoic spores and pollen grains from new, Zealand. New Zealand Geological Survey, Paleontaentological Bulletin, 22, 1-77.

Couper, R. A. (1958). British Mesozoic microspores and pollen grains. A systematic and stratigraphic study. Palaeontographica Abteilung B, $103,75-179$.

Courtinat, B. (2000). Review of the dinoflagellate cyst Subtilisphaera inaffecta (Drugg, 1978) Bujak and Davies, 1983 and S. paeminosa (Drugg, 1978) Bujak and Davies, 1983. Journal of Micropalaeontology, 19, 165-175.

D’Amato Avanzi, M. G. (1974). Mesozoic Spores and Pollen Grains from the Isle of Tavolara, Sardinia (Italy). Levigate Trilete Spores. Palaeontographia Italica, 67, 1-35.

Del Rio, M. (1976). Analisi palinologica del Giurese della Sardegna centrale. Bollettino Società Geologica Italiana, 95, 619-631.

Del Rio, M. (1984). Palynology of Middle Jurassic black organic shales of "Tacco di Laconi", Central Sardinia, Italy. Bollettino Società Paleontologica Italiana, 23, 325-342.

Del Rio, M. (1990). Palynological investigation in the Middle Jurassic of Nurra (Sardinia, Italy). Cagliari: Dipartimento di Scienze della Terra, Università di Cagliari.

Deng, S., \& Lu, Y. (2006). The Mesozoic dicksoniaceous ferns: characteristics, distribution, origin and evolutionary trends. Global Plant Letters, 1(1), 9-29.

Dercourt, J., Gaetani, M., Vrielynck, B., Barrier, E., Biju-Duval, B., Brunet, M. F., Cadet, J.-P., Crasquin, S., \& Sandulescu, M. (2000). Peri-Tethys Palaeogeographical Atlas. Paris: CCGM-CGMW.

Dettmann, M.E. (1963). Upper Mesozoic microfloras from south-eastern Australia. Proceedings of the Royal Society of Victoria, 1-152.
De Zigno, A. (1873-85) Flora Fossilis Formationis Oolithicae. Le plantae fossili dell'Oolite. Tipografia del seminario, Padova vol. 2.

Diéguez, C., Hernández, J. M., \& Pujalte, V. (2009). A fern-bennettitalean floral assemblage in Tithonian- Berriasian travertine deposits (Aguilar Formation, Burgos-Palencia, N Spain) and its palaeoclimatic and vegetational implications. Journal of Iberian Geology, 35(2), 127-140.

Dieni, I., Fischer, J. C., Massari, F., Salard-Cheboldaeff, M., \& VozeninSerra, C. (1983). La succession de Genna Selole (Baunei) dans le cadre de la paléogéographie mésojurassique de la Sardaigne orientale. Memorie di Scienze Geologiche, Padova, 36, 117-148.

Döring, H. (1965). Die sporenpaläontologische Gliederung des Wealden in Westmecklenburg. Geologische Beihefte, 14(47), 1-118.

Edwards, W. N. (1929). The Jurassic flora of Sardinia. Annals and Magazine of Natural History, 10, 385-394.

El Beialy, S. Y., Zalat, A., \& Ali, A. S. (2002). Palynology and palaeoenvironment of the Bahrein Formation, Zeitun-1 well, Western Desert, Egypt. Egyptian Journal of Palaeontology, 2, 371-384.

Falcon-Lang, H. J., Nelson, W. J., Elricks, S., Looy, C. V., Ames, P. R., \& DiMichele, W. A. (2009). Incised channel fi lls containing conifers indicate that seasonally dry vegetation dominated Pennsylvanian tropical lowlands. Geology, 37(10), 923-926.

Filatoff, J. (1975). Jurassic palynology of the Perth Basin, western Australia. Palaeontographica B, 154, 1-113.

Fontaine, W. M. (1889). The Potomac or younger Mesozoic flora. Monographs of the United States Geological Survey, 15, 1-377.

Francis, J. E. (1983). The dominant conifer of the Jurassic Purbeck Formation, England. Palaeontology, 26, 277-294.

Francis, J. E. (1984). The seasonal environment of the Purbeck (Upper Jurrasic) fossil forests. Palaeogeography, Palaeoclimatology, Palaeoecology, 48(2-4), 285-307.

Franz, M., Kaiser, S. I., Fischer, J., Heunisch, C., Kustatscher, E., Luppold, F. W., Berner, U., \& Röhling, H. G. (2015). Eustatic and climatic control on the Upper Muschelkalk Sea (late Anisian/ Ladinian) in the Central European Basin. Global and Planetary Change, 135, 1-27.

Gedl, P., \& Ziaja, J. (2012). Palynofacies from Bathonian (middle Jurassic) ore-bearing clays at Gnaszyn, Krakow-Silesia Homocline, Poland, with special emphasis on sporemorph ecogroups. Acta Geologica Polonica, 62, 325-349.

Gordenko, N. V. (2008). Middle Jurassic flora of the Peski locality (Moscow Region). Systematics, paleoecology, and phytogeography. Paleontological Journal, 42(12), 1285-1382.

Gothan, W. (1914). Die unter-liassische (rhätische) Flora der Umgegend von Nürnberg. Abhandlungen der naturhistorischen Gesellschaft Nürnberg, 19, 91-186.

Götz, A. E., Ruckwied, K., \& Barbacka, M. (2011). Palaeoenvironment of the Late Triassic (Rhaetian) and Early Jurassic (Hettangian) Mecsek Coal Formation (south Hungary): implications from macro-and microfloral assemblages. Palaeobiodiversity and Palaeoenvironments, 91(2), 75-88.

Grant, C. W. (1840). Memoir to illustrate a Geological Map of Cutch. Transactions Geological Society London, 5B, 289-330.

Greb, S. F., DiMichele, W. A., \& Gastaldo, R. A. (2006). Evolution and importance of wetlands in earth history. Geological Society of America, Special Paper, 399, 1-40.

Halle, T. G. (1913). The Mesozoic flora of Graham Land. Wissenschaftliche Ergebnisse der Schwedischen Südpolarexpedition, 19011903(3), 1-123.

Harris, T. M. (1949). Notes on the Jurassic flora of Yorkshire, 40-42. 40. Otozamites anglica (Seward) comb. nov.; 41. The narrow-leaved Otozamites species; 42. Ptilophyllum hirsutum Thomas and Bancroft and its differentiation from P. pecten (Phillips.) Annals and Magazine of Natural History London, 12th ser., 1, 275-299. 
Harris, T. M. (1961). The Yorkshire Jurassic Flora. I Thalophyta Pteridophyta. London: Trustees of the British Museum (Natural History).

Harris, T. M. (1964). The Yorkshire Jurassic Flora, II. Caytoniales, Cycadales and Pteridosperms. London: British Museum (Natural History).

Harris, T. M. (1969). The Yorkshire Jurassic Flora III. Bennettitales. British Museum (Natural History). London: British Museum (Natural History).

Harris, T. M. (1979). The Yorkshire Jurassic Flora V. Coniferales. British Museum (Natural History). London: British Museum (Natural History).

Harris, T. M. (1980). The Yorkshire Jurassic fern Phlebopteris braunii (Goeppert) and its reference to Matonia R. Br. Bulletin of the British Museum, Natural History (Geology), 33(5), 295-311.

Harris, T. M., Millington, W., \& Miller, J. (1974). The Yorkshire Jurassic Flora IV. 1. Ginkgoales, 2. Czekanowskiales. London: British Museum (Natural History).

Heer, O. (1876). Beiträge zur Jura-Flora Ostsibiriens und des Amurlandes. Mémoires de l'Académie impériale des sciences de St. Pétersbourg, Séries 7, 22, 72-74.

Heer, O. (1878). Beitrage zur fossilen Flora Siberiens und des Amurlandes. Mémoires de l'Académie Impériale des Sciences de St. Pétersbourg, serie 6, 7/25, 1-58.

Herman, A. B., \& Spicer, R. A. (1997). New quantitative palaeoclimate data for the Late Cretaceous Arctic: evidence for a warm polar ocean. Palaeogeography, Palaeoclimatology, Palaeoecology, 128, 227-251.

Herngreen, G. F. W. (2005a). Jurassic and Cretaceous sporomorphs of $N W$ Europe: taxonomy, morphology, ranges of marker species and zonation, with remarks on botanical relationship and ecology. Utrecht: TNO-NITG.

Herngreen, G. F. W. (2005b). Triassic sporomorphs of NW Europe: taxonomy, morphology and ranges of marker species, with remarks on botanical relationship and ecology, and comparison with ranges in the Alpine Triassic. Utrecht: TNO-NITG.

Hesselbo, S. P., Morgans-Bell, H. S., McElwain, J. C., Rees, P., Robinson, S. A., \& Ross, C. E. (2003). Carbon-Cycle Perturbation in the Middle Jurassic and Accompanying Changes in the Terrestrial Paleoenvironment. The Journal of Geology, 111, 259-276.

Hill, C. R. (1990). Ultrastructure of in situ fossil cycad pollen from the English Jurassic, with a description of the male cone Androstrobus balmei sp. nov. Review of Palaeobotany and Palynology, 65(1-4), $165-173$.

Hirmer, M., \& Hörhammer, L. (1936). Morphologie Systematik und geographische Verbreitung der fossilen und rezenten Matoniaceen. Palaeontographica, B, 81, 1-70.

Hubbard, R., \& Boulter, M. C. (2000). Phytogeography and paleoecology in western Europe and eastern Greenland near the Triassic-Jurassic boundary. PALAIOS, 15, 120-131.

Jadoul, F., Lanfranchi, A., Berra, F., Erba, E., Casellato, C. E., Cherchi, A., Simone, L., Schroeder, R., Carannante, G., \& Ibba, A. (2010). I sistemi carbonatici giurassici della Sardegna orientale (Golfo di Orosei) ed eventi deposizionali nel sistema carbonatico giurassicocretacico della Nurra (Sardegna nord-occidentale). Periodico semestrale dell'ISPRA - Servizio geologico d'Italia e della Società Geologica Italiana. Geological Field Trip, 2(2.1), 122. https://doi. org/10.3301/GFT.2010.02.

Jasper, K., Hartkopf-Froder, C., Flajs, G., \& Littke, R. (2010). Palaeoecological evolution of Duckmantian wetlands in the Ruhr Basin (western Germany): A palynological and coal petrographical analysis. Review of Palaeobotany and Palynology, 162, 123-145.

Kemp, E. (1970). Aptian and Albian miospores from southern England. Palaeontographica Abteilung B, 131, 73-143.
Kendall, M. W. (1949). On Brachyphyllum expansum (Sternberg) Seward, and its cone. Journal of Natural History, 12th ser., 2(16), 308-320.

Kilpper, K. (1964). Über eine Rät-Lias-Flora aus dem nördlichen Abfall des Alburs Gebirges in Nord-Iran. Teil 1: Bryophyta und Pteridophyta. Palaeontographica, B, 114, 1-78.

Knobloch, E., \& Mai, D. H. (1986). Monographie der Früchte und Samen in der Kreide von Mitteleuropa. Praha: Ústřední ústav geologický v Akademii, Československé Akademie.

Kostina, E. I., \& Herman, A. B. (2013). The Middle Jurassic flora of South Mongolia: composition, age and phytogeographic position. Review of Palaeobotany and Palynology, 193, 82-98.

Kostina, E. I., Herman, A. B., \& Kodrul, T. M. (2015). Early Middle Jurassic (possibly Aalenian) Tsagan-Ovoo Flora of Central Mongolia. Review of Palaeobotany and Palynology, 220, 44-68.

Krasser, F. (1912). Williamsonia in Sardinien. Sitzungsberichte Akademie der Wissenschaften in Wien, 121, 943-973.

Krasser, F. (1920). Doggerflora von Sardinien. Sitzungsberichte Akademie der Wissenschaften in Wien, 129, 1-26.

Kustatscher, E., Van Konijnenburg-van Cittert, J. H. A., \& Roghi, G. (2010). Macrofloras and palynomorphs as possible proxies for palaeoclimatic and palaeoecological studies: A case study from the Pelsonian (Middle Triassic) of Kuhwiesenkopf/Monte Pra della Vacca (Olang Dolomites, N-Italy). Palaeogeography, Palaeoclimatology, Palaeoecology, 290, 71-80.

Kustatscher, E., Heunisch, C., \& Van Konijnenburg-van Cittert, J. H. A. (2012). Taphonomical implications of the Ladinian megaflora and Palynoflora of Thale (Germany). PALAIOS, 27(11), 753-764.

Kustatscher, E., Franz, M., Heunisch, C., Reich, M., \& Wappler, T. (2014). Floodplain habitats of braided river systems: depositional environment, flora and fauna of the Solling Formation (Buntsandstein, Early Triassic) from Bremke and Fürstenberg (Germany). In E. Kustatscher, L. W. van den Hoek Ostende, H. Kerp (Eds.) Green planet - 400 million years of terrestrial floras. Papers in honour of JHA van Konijnenburg-van Cittert.Palaeobiodiversity and Palaeoenvironments, 94(2), 237270.

Kustatscher, E., Scanu, G. G., Kvaček, J., \& Van Konijnenburg-van Cittert, J. H. A. (2016). The Krasser collection in the Faculty of Sciences, Charles University, Prague-New insights into the Middle Jurassic Flora of Sardinia. Fossil Imprint, 72(3-4), 140-154.

Kustatscher, E., Bernardi, M., Petti, F. M., Franz, M., Kerp, H., Van Konijnenburg-van Cittert, J. H. A., \& Kerp, H. (2017). Sealevel changes in the Lopingian (late Permian) of the northwestern Tethys and their effects on the terrestrial palaeoenvironments, biota and fossil preservation. Global and Planetary Change, 148, 166-180.

Li, Y., Sun, C., LI, T., Na, Y., Chen, Y., \& Dehe, X. (2015). Solenites (Czekanowskiales) from the Late Mesozoic Jehol Biota of Southeastern Jilin, China and its Paleoclimatic Implications. Acta Geologica Sinica - English Edition, 89, 1088-1102.

Lindström, S., \& Erlström, M. (2006). The Late Rhaetian transgression in southern Sweden: regional (and global) recognition and relation to the Triassic-Jurassic boundary. Palaeogeography, Palaeoclimatology, Palaeoecology, 241, 339-372.

Madler, K. (1964). Die geologische Verbreitung von Sporen und Pollen in der Deutschen Trias. Beiheft zum Geologischen Jahrbuch, 65, 1147.

McElwain, J. C. (1998). Do fossil plants signal palaeoatmospheric carbon dioxide concentration in the geological past? Philosophical Transactions of the Royal Society of London B: Biological Sciences, 353(1365), 83-96.

McElwain, J. C., Popa, M. E., Hesselbo, S. P., Haworth, M., \& Surlyk, F. (2007). Macroecological responses of terrestrial vegetation to climatic and atmospheric change across the Triassic/Jurassic boundary in East Greenland. Paleobiology, 33(4), 547-573. 
Moeller, H. (1902). Bidrag till Bornholms fossila flora. Pteridofyter. Acta Universitatis Lundensis års-skrift, 13, 1-63.

Mohr, B. A. (1989). New palynological information on the age and environment of Late Jurassic and Early Cretaceous vertebrate localities of the Iberian Peninsula (eastern Spain and Portugal). Berliner Geowissenschaftlichen Abhandlungen, Reihe A, 106, 291-301.

Muller, J. (1959). Palynology of recent Orinoco delta and shelf sediments, reports of the Orinoco Shelf expedition. Micropalaeontology, 5(1), $1-32$.

Nathorst, A. G. (1897). Zur mesozoischen Flora Spitzbergens. Kungliga Svenska Vetenskapsakademiens Handlingar Stockholm, 30(1), 1-77.

Nilsson, T. (1958). Über das Vorkommen eines mesezoischen Sapropelgestreins in Schonen. Publication of the Institute of Mineralogy, Paleontology and Quaternary Geology of Lund, 53, $1-111$.

Nguyen Tu, T. T., Bocherens, H., Mariotti, A., Baudin, F., Pons, D., Broutin, J., Derenne, S., \& Largeau, C. (1999). Ecological distribution of Cenomanian terrestial plants based on $13 \mathrm{C} / 12 \mathrm{C}$ ratios. Palaeogeography, Palaeoclimatology, Palaeoecology, 145, 79-93.

Parrish, J. T., Peterson, F., \& Turner, C. E. (2004). Jurassic "savannah"plant taphonomy and climate of the Morrison Formation (Upper Jurassic, Western USA). Sedimentary Geology, 167, 137-162.

Phillips, J. (1875). Illustrations of the Geology of Yorkshire: or, a description of the strata and organic remains. Part I, The Yorkshire Coast (3rd ed.). London: R. Etheridge.

Pocock, S. A. J. (1970). Palynology of the Jurassic sediments of western Canada: Palaeontographica. B, 130, 12-136.

Popa, M. E. (1989). The Liassic continental flora of Romania-systematics, stratigraphy and paleoecology. AHBBuc, 1998, 177-184.

Popa, M. E. (1997). Corystospermal pteridosperms in the Liassic continental deposits of Romania. Acta Palaeontologica Romanica, 1, 81-87.

Popa, M.E. (2000) Early Jurassic land flora of the Getic Nappe. Bucharest: Faculty of Geology and Geophysics. University of Bucharest, $\mathrm{PhD}$ thesis.

Popa, M. E. (2014). Early Jurassic bennettitalean reproductive structures of Romania. In E. Kustatscher, L. W. van den Hoek Ostende, H. Kerp (Eds.) Green planet - 400 million years of terrestrial floras. Papers in honour of JHA van Konijnenburg-van Cittert.Palaeobiodiversity and Palaeoenvironments, 94(2), 327-362.

Popa, M. E., \& Meller, B. (2009). Review of Jurassic Plants from the Anina (Steierdorf) Coal Mining Area, South Carpathians, in the Collections of the Geological Survey of Austria. Jahrbuch der Geologischen Bundesanstalt, 149(4), 487-498.

Popa, M. E., \& Van Konijnenburg-van Cittert, J. H. A. (2006). Aspects of Romanian Early-Middle Jurassic palaeobotany and palynology. Part VII. Successions and floras. Progress Natural Sciences, 16, 203-212.

Potonié, R. (1967). Versuch der Einordnung der fossilen Sporae dispersae in das phylogenetischen System der Pflanzenfamilien. Forschungsberichte des Landes Nordrhein-Westfalen, 1761, 11310.

Pott, C., \& McLoughlin, S. (2009). Bennettitalean foliage in the Rhaetian-Bajocian (latest Triassic-Middle Jurassic) floras of Scania, southern Sweden. Review of Palaeobotany and Palynology, 158, 117-166.

Pott, C., Krings, M., \& Kerp, H. (2007). A surface micro-relief on the leaves of Glossophyllum florinii (?Ginkgoales) from the Upper Triassic of Lunz, Austria. Botanical Journal of the Linnean Society, 153, 87-95.

Pott, C., Krings, M., \& Kerp, H. (2008). The Carnian (Late Triassic) flora from Lunz in Lower Austria: palaeoecological considerations. Palaeoworld, 17, 172-182.

Raine, J. I., De Jersey, N. J., \& Ryan, K. G. (1988). Ultrastructure and lycopsid affinity of Densoisporites psilatus (de Jersey) comb. nov. from the Triassic of New Zealand and Queensland. Memoir of the Association of Australasian Palaeontologists, 5, 79-88.

Raine, J.I., Mildenhall, D.C., \& Kennedy, E.M. (2005) New Zealand fossil spores and pollen: an illustrated catalogue. Institute of Geological and Nuclear Sciences Information, Series 68.

Rees, P. M., Ziegler, A. M., \& Valdes, P. J. (2000). Jurassic phytogeography and climates: new data and model comparisons. In B. T. Huber, K. G. Macleod, \& S. L. Wing (Eds.), Warm climates in earth history. (297-318 p.). Cambridge: Cambridge University Press.

Retallack, G. J. (1975). The life and times of a Triassic lycopod. Alcheringa, 1(1), 3-29.

Retallack, G. J. (1997). Earliest Triassic origin of Isoetes and quillwort evolutionary radiation. Journal of Paleontology, 71(3), 500-521.

Reyre, Y. (1980). Peut-on estimer l'evolution des climats Jurassiques et Cretaces d'apres la palynologie? Mémoires du Muséum national d'histoire naturelle, nouvelle série, B, 27, 247-260.

Samylina, V. A., \& Kiritchkova, A. I. (1993). The genus Czekanowskia Heer: principles of systematics, range in space and time. Review of Palaeobotany and Palynology, 79(3-4), 271-284.

Scanu, G. G., Kustatscher, E., \& Pittau, P. (2012). The Jurassic plant fossils of the Lovisato Collection: preliminary notes. Bollettino della Società Paleontologica Italiana, 51(2), 71-84.

Scanu, G. G., Kustatscher, E., \& Pittau, P. (2015). The Jurassic Flora of Sardinia - a new piece in the palaeobiogeography puzzle of the Middle Jurassic. Review of Palaeobotany and Palynology, 218 , 80-105.

Scanu, G. G., Kustatscher, E., Pittau, P., \& van Konijnenburg-van Cittert, J. H. A. (2016). New insights into the Middle Jurassic floras of Sardinia (Italy) - The Miccolis Collection at the Museo di Scienze Naturali of Venice, Italy. Bollettino della Società Paleontologica Italiana., 55(1), 29-45.

Schenk, A. (1875). Beiträge zur Flora der Vorwelt, V. Zur Flora der nordwestdeutschen Wealdenformation. Palaeontographica, 23, $157-172$.

Schneider, H. H. (1978). A Jurassic coal seam at the Genna su Ludu (Sardinia) - its stratigraphic and palaeogeographic significance. Neues Jahrbuch für Geologie und Paläontologie, Monatshefte, 12, 734-740.

Schopf, J. M., Wilson, L. R., \& Bentall, R. (1944). An annotated synopsis of paleozoic fossil spores: And the definition of generic groups. Illinois Geological Survey Report Inv, 91, 1-72.

Schulz, E. (1967). Sporenpaläontologische Untersuchungen rätoliassischer Schichten im Zentralteil des Germanischen Beckens. Paläontologische Abhandlungen, Paläobotanik B, 2, 427-633.

Seward, A. C. (1894). The Wealden Flora, Part I. ThallophytaPteridophyta. Catalogue of the Mesozoic Plants in the Department of Geology, British Museum. London: The Trustees of the British Museum.

Seward, A. C. (1900). Catalogue of the Mesozoic plants in the Department of Geology, British Museum (Natural History). The Jurassic flora. I. The Yorkshire Coast. London: British Museum (Natural History).

Seward, A. C. (1919). Fossil plants, IV Ginkgoales, Coniferales, Gnetales. Cambridge: Cambridge University Press.

Shang, Y., \& Zavada, M. S. (2003). The ultrastructure of Cerebropollenites from the Jurassic and Cretaceous of Asia. Grana, 42(2), 102-107.

Spicer, R. A., \& Hill, C. R. (1979). Principal components and correspondence analyses of quantitative data from a Jurassic plant bed. Review of Palaeobotany and Palynology, 28, 273-297.

Srivastava, K. (1977). Microspores from the Fredericksburg group (Albian) of the southern UnitedStates. Paleobiologie Continentale, 6(1975), 1-119.

Stampfli, G. M. (2000). Tethyan oceans. In E. Bozkurt, J. A. Winchester, \& J. D. A. Piper (Eds.), Tectonics and Magmatism in Turkey and the 
Surrounding Area. London: Geological Society Special Publications, 173.

Steinthorsdottir, M., Bacon, K. L., Popa, M. E., Bochner, L., \& McElwain, J. C. (2011). Bennettitalean leaf cuticle fragments (here Anomozamites and Pterophyllum) can be used interchangeably in stomatal frequency-based palaeo-CO2 reconstructions. Palaeontology, 54, 867-882.

Sternberg K.M. von (1820-38) Versuch einer geognostisch-botanischen Darstellung der Flora der Vorwelt. vol. 1, pp. 88; vol. 2, pp. 220. Leipzig, Prague.

Suárez-González, P., Quijada, I. E., Benito, M. I., \& Mas, R. (2015). Sedimentology of ancient coastal wetlands: insight from a Cretaceous multifaceted depostional system. Journal of Sedimentary Research, 85, 95-117.

Sun, C., Wang, H., Dilcher, D. L., Li, T., Li, Y., \& Na, Y. (2015). A new species of Czekanowskia (Czekanowskiales) from the Middle Jurassic of Ordos Basin, China. Botanica Pacifica, 4(2), 149-155.

Thevenard, F., Gomez, B., \& Daviero-Gomez, V. (2005). Xeromorphic adaptations of some Mesozoic gymnosperms. A review with palaeoclimatological implications. Comptes Rendus Palevol, 4(2005), 67-77.

Thomas, H. H. (1911). On the spores of some Jurassic ferns. Cambridge Philosophical Society Proceedings, 16, 384-388.

Tosolini, A.-M. P., McLoughlin, S., Wagstaff, B. E., Cantrill, D. J., \& Gallagher, S. J. (2015). Cheirolepidiacean foliage and pollen from Cretaceous high-latitudes of southeastern Australia. Gondwana Research, 27, 960-977.

Townrow, J. A. (1962). On Pteruchus, a microsporophyll of the Corystosper maceae. Bulletin of the British Museum (Natural History) Geology, 6, 287-320.

Tralau, H. (1967). Some Middle Jurassic microspores of Southern Sweden. Geologiska föreningen, 89(4), 469-472.

Tralau, H. (1968). Botanical investigations into the fossil flora of Eriksdal in Fyledalen, Scania. II. The Middle Jurassic Microflora. Sveriges Geologiska Undersokning. Series C, 633, 1-185.

Traverse, A. (2007). Paleopalynology. In N. H. Landman \& D. S. Jones (Eds.), Topics in Geobiology. Dordrecht: Springer.

Tyson, R. V. (1995). Abundance of organic matter in sediments: TOC, hydrodynamic equivalence, dilution and flux effects. In Sedimentary organic matter (pp. 81-118). Springer: Netherlands.

Vakhrameev, V. A. (1970). Pattern of distribution and Palaeoecology of Mesozoic conifers Cheirolepidiaceae. Paleontological Journal, 1(1970), 19-34.

Vakhrameev, V. A. (1981). Pollen Classopollis: indicator of Jurassic and Cretaceous climates. Palaleobotanist, 28-29, 301-307.

Vakhrameev, V. A. (1991). Jurassic and Cretaceous floras and climates of the earth. Cambridge: Cambridge University Press.

Vakhrameev, V. A., Dobruskina, I. A., Zalkinskaya, Y. D., \& Meyen, S. V. (1970). Paleozoic and Mesozoic floras of Eurasia and the phytogeography of that time. Akademie Nauka SSSR Institute Trudy, 208, 1 424 (in Russian).

Van de Schootbrugge, B. (2010). A fiery start to the Jurassic. Nature Geoscience, 3, 381-382.

Van Konijnenburg-van Cittert, J. H. A. (1971). In situ gymnosperm pollen from the Middle Jurassic of Yorkshire. Acta Botanica Neerlandica, 20(1), 1-97.

Van Konijnenburg-van Cittert, J. H. A. (1989). Dicksoniaceous spores in situ from the Jurassic of Yorkshire, England. Review of Palaeobotany and Palynology, 61, 273-301.
Van Konijnenburg-van Cittert, J. H. A. (1993). A review of the Matoniaceae based on in situ spores. Review of Palaeobotany and Palynology, 78, 235-267.

Van Konijnenburg-van Cittert, J. H. A. (2002). Ecology of some Late Triassic to early Cretaceous ferns in Eurasia. Review of Palaeobotany and Palynology, 119, 113-124.

Van Konijnenburg-van Cittert, J. H. A., \& Morgans, H. S. (1999). The Jurassic flora of Yorkshire. Field guide to fossils No. 8. London: The Palaeontological Association.

Van Konijnenburg-van Cittert, J. H. A., \& Van der Burgh, J. (1989). The flora from the Kimmeridgian (Upper Jurassic) of Culgower, Sutherland, Scotland. Review of Palaeobotany and Palynology, 61, $1-51$.

Van Konijnenburg-van Cittert, J. H. A., \& Van der Burgh, J. (1996). Review of the Kimmeridgian flora of Sutherland, Scotland, with reference to the ecology and in situ pollen and spores. Proceedings of the Geologists' Association, 107(2), 97-105.

Van Konijnenburg-van Cittert, J. H. A., Kustatscher, E., Bauer, K., Pott, C., Schmeißner, S., Dütsch, G., \& Krings, M. (2014). A selaginellitesfrom the Rhaetian of Wüstenwelsberg (Upper Franconia, Germany). Neues Jahrbuch fur Geologie und Palaontologie, Abhandlungen, 272(2), 115-127.

Van Konijnenburg-van Cittert, J. H. A., Kustatscher, E., Pott, C., Schmeissner, S., Dütsch, G., \& Krings, M. (2016). New data on Selaginellites coburgensis from the Rhaetian of Wüstenwelsberg (Upper Franconia, Germany). Neues Jahrbuch fur Geologie und Palaontologie, Abhandlungen, 280(2), 177-181.

Visscher, H., \& Van der Zwan, C. J. (1981). Palynology of the circumMediterranean Triassic: phytogeographical and palaeoclimatological implications. Geologische Rundschau, 70(1-2), 625-634.

Waksmundzka, M. (2014). Mesozoic spores of Poland. A revision of selected taxa. Biuletyn Panstwowego Instytutu Geologicznego, $460,25-28$.

Wang, Y. D. (2002). Fern ecological implications from the Lower Jurassic in Western Hubei, China. Review of Palaeobotany and Palynology, 119, 125-141.

Wang, Y., Mosbrugger, V., \& Zhang, H. (2005). Early to Middle Jurassic vegetation and climatic events in the Qaidam Basin, Northwest China. Palaeogeography, Palaeoclimatology, Palaeoecology, 224(1-3), 200-216.

Watson, J. (1988). The Cheirolepidiaceae. In C. B. Beck (Ed.), Origin and evolution of gymnosperms. New York: Columbia University Press.

Watson, J., \& Sincock, C. A. (1992). Bennettitales of the English Wealden. Monograph of the Palaeontographical Society, 145(588), 2-228.

Zavialova, N., \& Van Konijnenburg-van Cittert, J. H. (2011). Exine ultrastructure of in situ peltasperm pollen from the Rhaetian of Germany and its implications. Review of Palaeobotany and Palynology, 168(1), 7-20.

Zavialova, N., van Konijnenburg-van Cittert, J., \& Zavada, M. (2009). The pollen ultrastructure of Williamsoniella coronata Thomas (Bennettitales) from the Bajocian of Yorkshire. International Journal of Plant Sciences, 170(9), 1195-1200.

Zhou, Z.-Y. (2009). An overview of fossil Ginkgoales. Palaeoworld, $18(1), 1-22$.

Ziaja, J. (2006). Lower Jurassic spores and pollen grains from Odrowąż, Mesozoic margin of the Holy Cross Mountains, Poland. Acta Palaeobotanica, 46, 3-83. 